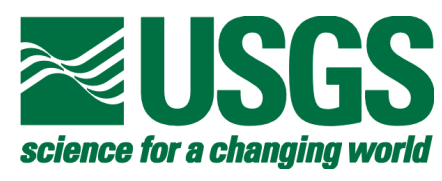

\title{
Gravity Study of the Guernsey Landfill Site, Guernsey, Wyoming
}

\author{
By Michael W. Webring, Robert P. Kucks, and Jared D. Abraham
}

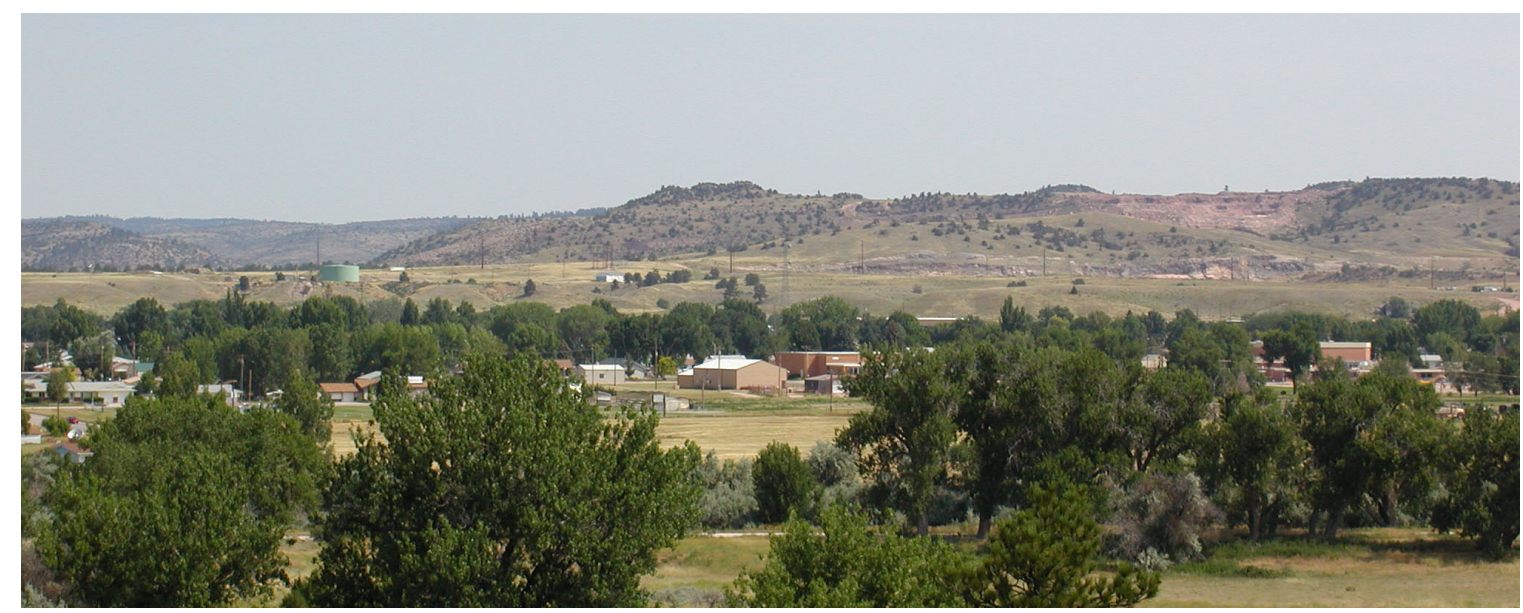

Any use of trade names is for descriptive purposes only and does not imply endorsement by the U.S. Government.

Open-File Report 2004-1383

U.S. DEPARTMENT OF THE INTERIOR

U.S. GEOLOGICAL SURVEY 


\section{Introduction}

A gravity survey was conducted near the Camp Guernsey cantonment area and the town of Guernsey, Wyoming, to characterize the bedrock topography and surficial deposits. The survey was performed by personnel from the United States Geological Survey (USGS) Geologic Discipline in cooperation with the USGS Water Resources Discipline, the Wyoming Department of Military Affairs, and the town of Guernsey. From July 9 to July 19, 2003, fifty-two stations were established in the inactive landfill north of town, and eleven stations were established across the North Platte River valley through the town of Guernsey and west of the cantonment area.

The landfill is situated on the southern flank of the Hartville uplift (Harris, 1997) on a river terrace approximately 16 meters above the North Platte River valley (fig. 1 and 2). Dense metadolomite is quarried immediately east of the landfill. The metadolomite and overlying metabasalt crop out in the area of the quarry. In the area of the landfill at the bottom of the deepest ravine is an outcrop of limestone interpreted to be a member of the Hartville formation that overlies the dolomite and basalt. The remainder of the area is covered with terrace gravels.

An overall accuracy in the range of tens of $\mu \mathrm{Gal}\left(1 \mu \mathrm{Gal}=10^{-8}\right.$ meter/second $\left.{ }^{2}\right)$ and station spacing on the order of tens of meters were considered appropriate to characterize the basement and enable stripping of the alluvial signature. A digital gravimeter and real-time kinematic (RTK) Global Positioning System (GPS) were used to gather data, and some comments are noted for their use in this setting. In addition, vertical datum conversion and gravity anomaly computation are described in relation to emerging standards.

In addition to the gravity survey, a direct-current (DC) resistivity survey (McDougal and others, 2004) was conducted to characterize the water table and the stratigraphic section.

\section{Gravity data}

A LaCoste-Romberg (L\&R) gravimeter with Aliod100 electrostatic beam nulling and digital readout was used to measure the gravity field. Data were recorded on a Palm Pilot connected by a serial cable to the Aliod electronics box attached to the outside of the gravimeter. The gravimeter sensor is in the standard L\&R thermostatically controlled enclosure, and when the Aliod is in operation, pendulum levels inside the enclosure drive meters the operator uses to level the instrument instead of the standard spirit levels outside the enclosure. Although all readings in this survey were obtained with the electronic nulling, the Aliod electronics may be turned off and the meter leveled via the spirit bubbles and read visually through a microscopic eyepiece.

Each station requires about 15 to 20 minutes to obtain a reading, including setup and teardown. The digital output of the meter stabilizes within 2 minutes of unclamping the beam and then slowly drifts about $10 \mu \mathrm{Gal}$ to the final reading. To avoid the limitations 
of reading for a short period at a constant time after unclamping, the meter was read at 15-second intervals starting 6 minutes after unclamping and continuing for 3 to 4 minutes. If the readings were consistent and stable, then the last 1 or 2 minutes of readings were averaged to produce a single reading. The digital output has a resolution of $1 \mu \mathrm{Gal}$, and $0.1 \mu \mathrm{Gal}$ was used for data reduction. Laboratory tests with this gravimeter indicate repeat measurements on the order of $\pm 2 \mu \mathrm{Gal}$ are common with the electrostatic nulling system, which is about 3 times better than measurements obtained using optical and manual beam nulling.

Base stations were read at 1- to 1.5-hour intervals which allowed, at most, three to four station readings in each base loop. Up to six base station loops were collected each day. Most of the stations in the landfill area were read at least twice, and when the difference exceeded about $10 \mu \mathrm{Gal}$, the stations were reread. Two base stations (g01 and g21, fig. 3 ) were used in the landfill area, and the seven repeat readings of the second base with respect to the first yield a standard deviation of $5 \mu \mathrm{Gal}$. A single tie to the International Gravity Standardization Net 1971 (IGSN71) base station (Morelli,1974) in Wheatland was done. The principal facts for the survey appear in Appendix A.

The long-term drift rate of the meter operated in the laboratory is in the range of 1 to $2 \mu \mathrm{Gal}$ per hour. In the field, the drift rate is substantially higher with 10 to $20 \mu \mathrm{Gal}$ per hour not uncommon, and several loops had up to $30 \mu \mathrm{Gal}$ per hour. Some of the higher drift rate is from small tares caused by normal handling, but some is caused by abrupt changes in temperature. To compensate, the meter was equilibrated to the ambient temperature for at least 1 hour before starting measurements and was exposed to the ambient temperature, either in the shade of the operator or outside the truck, whenever possible. On several occasions, the digital readout would not stabilize, and the meter would require re-equilibration in a location with reduced radiant heating.

Appendix B contains a summary of statistics from repeated stations. Overall, the range of the relative gravity readings at a station did not exceed $37.3 \mu \mathrm{Gal}$ with an average range of $10.5 \mu \mathrm{Gal}$. As mentioned previously, tares are suspected for some of these larger variations, and examination of the entire data set shows almost all the data collected on July 12th and 13th contribute an extreme value to the range of station values. When these days are removed from the data along with four other extremes, the maximum range of the gravity readings drops to $14.4 \mu \mathrm{Gal}$ with an average range of $5.9 \mu \mathrm{Gal}$. The poor repeat values for the 12 th and 13 th were noticed in the field, and the procedure was changed to ensure the meter and base plate were always shaded. A persistent light wind helped keep the meter at ambient temperature even in the presence of heat reflected from the ground as the temperature rose to 106 degrees Fahrenheit later in the survey.

\section{Position surveying}

Stations were located with a Javad Legacy-E dual frequency, phase comparing, real-time differential Global Positioning System (GPS) unit. A benchmark southeast of town, National Geodetic Survey (NGS) id-number NQ0176 and stamped "Z 63" (Appendix C), 
is the base for the coordinates of the gravity survey. This benchmark is a Federal Base Network Control Station (http://www.ngs.noaa.gov/) and has up-to-date GPS derived horizontal and vertical coordinates in the North American Datum of 1983 (NAD83). The specific horizontal datum is denoted as NAD83(93) in Appendix C. A local Javad base near gravity station g21 was established and was used for all subsequent surveying. Two other benchmarks in the vicinity were occupied as a check on the overall position surveying. These benchmarks are listed in Appendixes A and B as gravity stations bh2 and bh4, and the surveyed elevation, rounded to the nearest foot, agrees with the elevation listed on the published USGS topographic map.

The Javad was operated in static mode with the antenna mounted on a range rod while surveying station points. It provides horizontal coordinates with an error of about 17 millimeters and a slightly greater vertical error with an occupation time of about 1 minute. Topographic mapping was performed with the unit mounted in a backpack and the user walking at a normal pace. The sampling rate was one per second.

Most of the landfill was surveyed in kinematic mode, and the coverage may be seen in figure 3 as the color contour background. About 9 hours, plus in-field upload and processing time, were required to collect the topographic data. Coverage is more dense near gravity stations to allow good definition for terrain correction and less dense away from the gravity stations, where the relief is low. The surveyed area combined with the USGS 10-meter digital elevation model (DEM), shifted to NAD83 horizontal and vertical coordinates, is shown in perspective view in figure 2 gridded at a 1 meter interval.

Gravity stations were located on small cleared areas with vegetation and rocks removed. Surveyed locations are at ground level in the center of these cleared areas. The ground clearance of the gravity meter base plate was noted for each reading, but the plate location may be summarized as either pressed into the ground for stability or sitting above ground level on the points of the plate tripod.

\section{Vertical datum conversion}

With the advent of high accuracy GPS surveying and geoid models, new gravity surveys may use either orthometric elevations based on the geoid or height above the reference ellipsoid. The geoid is the presumed location of sea level in a location, however, that location or surface varies according to large-scale gravity variations, and referencing gravity calculations on it causes what is known as the indirect effect (Chapman and Bodine, 1979 or Li and Götze, 2001).

Emerging gravity standards likely will favor the International Terrestrial Reference Frame (ITRF) coordinate system as the single global reference, but currently those standards can be met only if there is a benchmark with updated coordinates nearby or if the survey party can occupy a point with a dual frequency GPS for several hours over multiple days. Documentation of the details of station altitude will allow this and other new gravity surveys to be merged with older surveys, which used the NGVD29 in the 
conterminous United States. The relations among the various vertical coordinates can be summarized in this area with a set of algebraic shifts.

NAVD88 $=$ VERTCON + NGVD29

NAD83 = GEOID99 + NAVD88

\section{explanation:}

NGVD29 National Geodetic Vertical Datum of 1929, approximately orthometric elevations (height above geoid). The datum commonly found on all but the latest USGS topographic maps.

VERTCON A grid of elevation shifts to convert the NGVD29 orthometric elevations to a more consistent orthometric elevation (available at http://www.ngs.noaa.gov).

NAVD88 North American Vertical Datum of 1988, orthometric elevations (height above the geoid, the presumed sea level that would occur in the area).

GEOID99 A grid of geoid heights above the GRS80 ellipse in the NAD83 vertical datum (Smith and Roman, 2001).

NAD83 North American Datum of 1983 height above the GRS80 ellipsoid, but with an approximately 1 to 2 meter origin shift that does not make the ellipse geocentric. This is a specific datum in reference to the ITRF. The ITRF varies slightly in time due to improved technique and continental drift and is the basis for WGS84 coordinates output by GPS units.

WGS84 World Geodetic System of 1984 is the geocentric system of coordinates used by the Global Positioning System. WGS84 epoch G1150 is equivalent to ITRF00, and both are current as of mid 2003.

In this area VERTCON $=0.78$ meter and GEOID99 $=-14.95$ meter. It should be noted that the NAD83 and WGS84 height above the ellipsoid is not the same, and in this vicinity, the difference is about 0.8 meter.

Regardless of the above, the USGS 10-meter DEM generated from the NGVD29 contours of the original 1955 topographic map required a locally determined shift of -16.95 meters to more closely match the Javad surveying. This shift was determined by the average difference between the two data sets in undisturbed low-relief areas outside the landfill. Since the VERTCON and GEOID99 shifts sum to -14.17 and -16.95 was applied to the 10-meter DEM, there is a difference of 2.78 meters between the surveyed data and the DEM. The GPS surveyed altitudes agree with the mapped benchmark altitudes rounded to the nearest foot and the 20 foot (6.1 meter) contoured DEM visually agrees with the contours of the topographic map. The combined elevation model is used for terrain correction to a radius of 2.615 kilometers from each gravity station.

\section{Gravity data reduction}

In the field, meter readings were converted to relative gravity in $\mathrm{mGal}(1 \mathrm{mGal}=$ $10^{-5} \mathrm{~m} / \mathrm{s}^{2}$ ) and tide corrected (Longman, 1959). Linear drift correction was applied by using station $\mathrm{g} 01$ in the northwest corner of the landfill as the primary base or station $\mathrm{g} 21$ 
as a secondary base on the south side of the area. As the survey progressed, the tie between g01 and g21 was reread until the distribution of the error could be quantized. As previously mentioned, the error has a standard deviation of $5 \mu \mathrm{Gal}$.

A single loop to connect g01 to the IGSN71 base station in Wheatland was performed. The Wheatland gravity benchmark was not recovered, although a stamped description was found on a supporting member of the beacon tower under which the benchmark should have been located. The length of the loop was 3 hours, with a modest $-15 \mu \mathrm{Gal}$ per hour drift, so the tie should be well within the stated accuracy of $100 \mu \mathrm{Gal}$, including lack of altitude recovery. The absolute gravity at the Wheatland base is given as 979,913.79 mGal (Morelli, 1974).

Terrain correction was computed from the station to a radius of 166.7 kilometers in two separate computations, with the division at $2.615 \mathrm{~km}$. The inner portion ends at Hammer zone $\mathrm{H}$ (Hammer, 1939), and the outer portion ends at Hayford-Bowie zone O (Hayford and Bowie, 1912). The outer correction was computed with computer program OUTERTC (Plouff, 1977). The inner zone was computed with program DCTC (Webring, unpublished program). The Plouff algorithm uses elevation models of .25, 1, and 3 arc-minute resolution and a spherical Earth. The DCTC (Digitized Contour Terrain Correction) program creates the elevation model on the fly by using random surveyed points and, in this instance, the USGS 10-meter DEM, converted to XYZ, for the area immediately around the landfill. DCTC starts with a grid of 192-meter interval for zone $\mathrm{H}$, interpolated with minimum curvature (cf. Webring, 1981) enhanced with a tension factor (Smith and Wessel, 1990), and then subdivides and reconverges the grid for successively closer zones ending with one meter at zone A.

The outer zone correction varies from -47 to $-63 \mu \mathrm{Gal}$ at $2.67 \mathrm{gm} / \mathrm{cc}$, while the inner correction varies from 98 to $337 \mu \mathrm{Gal}$. Negative outer zone terrain corrections can occur in areas of low relief. The largest inner correction occurs in a section of profile that descends 16 meters from the alluvial terrace to the level of the Platte River Valley. Numerical tests with this section of profile indicate horizontal movement of the station by 0.1 meter varies the inner zone correction less than $1 \mu \mathrm{Gal}$ while vertical movement of the station by 0.01 meter varies the correction by about $5 \mu \mathrm{Gal}$.

The ellipsoidal Free Air and Bouguer anomalies were computed following recommendations of the North American Gravity Database Standards Committee (oral commun.). As defined by the geodetic community, the gravity anomaly is referenced to the geoid, and the gravity disturbance is referenced to the ellipsoid (Heiskanen and Moritz, 1969); however, the emerging terminology is to prefix the adjective "ellipsoidal" to anomaly calculations based on ellipsoidal heights. The ellipsoidal Free Air anomaly was computed using a theoretical gravity and atmospheric correction (Moritz, 1980) and second-order height correction (Heiskanen and Moritz, 1969). Each is referenced to the GRS 1980 ellipsoid. The ellipsoidal Bouguer anomaly was computed using a spherical terrain cap (LaFehr, 1991) and a terrain correction on an Earth with a radius of 6,371 kilometers. The terrain model (spherical cap minus terrain correction) for the Bouguer anomaly was computed using a density of 2.67 grams per cubic centimeter $(\mathrm{gm} / \mathrm{cc})$. 
The station altitudes and topographic data were surveyed in the NAD83 vertical datum rather than the recommended ITRF vertical datum (the one used by GPS) because the software for that conversion was not available at the time the data were reduced. However, the NAD83/ITRF altitude shift varies smoothly from an amplitude of about 0.3 meter to about 1.6 meter over the conterminous United States, so the shift may be approximated as a constant in a local area. The computed anomalies for this survey therefore have a small constant offset that may be properly ignored.

Bouguer contours and station locations for the landfill area and the profile south across the North Platte River valley are shown on figure 4. Curvature of the contours at the edge of the data, especially at the south end of the North Platte River valley profile, are artifacts of the gridding process. No prior smoothing was done on any figure, however, the display program seems to have a spline-based interpolation operation in place.

\section{Regional gravity field}

The existing gravity stations for about a 100 kilometer radius around the study area were reduced to the Bouguer anomaly and the resulting regional field lowpassed with a 100 kilometer filter. This regional gravity field can be interpreted as crustal thickness variations and the effects of distant sedimentary basins. In the area of this survey, the regional gravity field is a plane dipping southeast with a $1 \mathrm{mGal}$ difference in amplitude from north to south. The regional gravity field was subtracted from the Bouguer anomaly to produce the residual Bouguer anomaly shown on figure 5. A strong north-south gradient remains that indicates the core of the Hartville uplift to the north. In retrospect, this survey did not go far enough north to define the gravity response of the shallow versus the deeper, larger scale structure of the Hartville uplift.

\section{Density of hand samples}

Several hand samples were collected and measured for density to aid the interpretation. Two samples of each rock type were used:

- Metadolomite from the quarry: $2.82 \mathrm{gm} / \mathrm{cc}$.

- Metabasalt from hill north of the quarry: $2.64 \mathrm{gm} / \mathrm{cc}$.

- Recrystallized limestone from ravine outcrop in landfill area: $2.66 \mathrm{gm} / \mathrm{cc}$.

- Gray friable sandstone from outcrop south of town, tentatively identified as Arikaree formation (Harris, 1997): dry $1.43 \mathrm{gm} / \mathrm{cc}$, saturated $1.83 \mathrm{gm} / \mathrm{cc}$.

\section{Density of the surficial terrace gravel}

The terrain corrections listed in Appendix A are computed at a standard $2.67 \mathrm{gm} / \mathrm{cc}$ (Hinze, 2003) that, when subtracted from a constant thickness spherical cap, result in a gravity model from the topographic surface down to the reference ellipsoid and radially out from the station to 166.7 kilometers. Adding this terrain model effect to the gravity predicted in the Free-Air anomaly calculation results in a terrain-free gravity known as 
the Bouguer anomaly. If the terrain has a consistent density of $2.67 \mathrm{gm} / \mathrm{cc}$, as many mountainous areas of granitic composition have, then all topographic effects are removed, and only anomalous subsurface variations remain.

The recrystallized limestone found in the ravine as well as the metabasalt have densities very close to the standard $2.67 \mathrm{gm} / \mathrm{cc}$ and are accounted for with the standard anomaly calculation. The metadolomite is more dense and can cause gravity anomalies if it varies from a uniformly horizontal slab. The overlying terrace gravels found at the surface in the landfill will have a lower than standard density, because there is a high percentage of pore space between the uncemented grains, and the irregular topographic surface will, therefore, cause an anomaly. Other rock formations with nonstandard densities are far enough distant to affect all stations equally.

The gravity of the topography close to the station can be computed in a fashion similar to the standard Bouguer topographic model. A terrace model was constructed that extends 170 meters from the stations (Hammer zone D) and down to an altitude of 1,323 meters, just below the elevation of station g42, the lowest landfill area station. The model is a flat-bottomed cylinder with the topography as the top surface of the cylinder, and the density used in the calculation is relative to $2.67 \mathrm{gm} / \mathrm{cc}$. Separate model computation was centered on each station. The results for profiles 1,2 , and 3 are shown on figures 6,7 , and 8 as distance versus station altitude (red) in the bottom panel and Bouguer anomaly (green) in the top panel. The several curves located above the Bouguer anomaly curve are the result of terrace gravel models at different densities added to the Bouguer anomaly.

Nettleton (1939) first proposed the examination of density with relation to topography, and the three profile figures show the results for terrace densities of 1.4, 1.6, 1.8, 2.0, and $2.2 \mathrm{gm} / \mathrm{cc}$. Examination of the south end of profile 2 on figure 7 reveals a strong topographic effect caused by using a Bouguer reduction density of $2.67 \mathrm{gm} / \mathrm{cc}$. The Bouguer anomaly curve in green shows an abrupt change in curvature and smoothness from stations g24 to g30, which are located on the greatest slope where the terrain correction is highest (station g26 has the highest inner zone correction of $337 \mu \mathrm{Gal}$ ). The south end of profile 2 indicates the density of the terrace gravel is somewhat less than $2.67 \mathrm{gm} / \mathrm{cc}$, since all the model curves are smoother than the Bouguer curve. However, the 2.5-D model shown later indicates a dense basement mass with top-surface relief (for instance, not flat topped) inside the topographic mass outlined by the altitude curve on figure 7. Therefore, the overall curvature and derived density from stations g24 to g29 is driven by a combination of terrace gravel and basement rock density .

The specific curvature referred to in the following is an estimate of the second horizontal derivative centered on the $i^{\text {th }}$ point. The stations are assumed to be equally spaced in distance, and an estimate of the curvature may be computed with the relation: $c_{i}=z_{i-1}-2 z_{i}+z_{i+1}$, where $\mathrm{z}$ is any measured quantity with relation to distance. When the three $\mathrm{z}$ values are collinear, the curvature is zero, and the quantity in question has no correlation with another quantity that has a nonzero curvature. 
Another location to apply the Nettleton method is in the center of profile 1, enlarged on figure 9. Stations g8, g4, and g11 are located at slope breaks as seen in the bottom panel of figure 9, and the green Bouguer anomaly curve is inversely correlated with the station altitude. The terrace model curves above the Bouguer curve become straight (for instance, no correlation with topography) between densities 2.2 and $1.4 \mathrm{gm} / \mathrm{cc}$. Specifically, station g8 at density $1.7 \mathrm{gm} / \mathrm{cc}$, station g4 at density $2.1 \mathrm{gm} / \mathrm{cc}$, and station $\mathrm{g} 11$ at density $1.8 \mathrm{gm} / \mathrm{cc}$, which average to $1.87 \mathrm{gm} / \mathrm{cc}$. Tests on the profile 1 stations with more localized models (Hammer zone B at 16.6 meter radius and shorter cylinders) indicate densities of $1.6,2.0$, and $1.8 \mathrm{gm} / \mathrm{cc}$ respectively, which average to $1.8 \mathrm{gm} / \mathrm{cc}$. There are three candidates for density determination in profile 2 using the 16.6 meter model; stations g23 with $1.6 \mathrm{gm} / \mathrm{cc}$, g25 with $2.0 \mathrm{gm} / \mathrm{cc}$, and g27 with $1.6 \mathrm{gm} / \mathrm{cc}$. Station g27 is located in a section of the profile with consistently negative curvature, and the density derived at this location likely is driven by the basement rock previously mentioned.

In summary, the terrace gravel bulk density derived by the Nettleton technique is about $1.8 \mathrm{gm} / \mathrm{cc}$. There is a large variation of the densities included in this determination, and too few samples for meaningful statistics. To give an idea of the data accuracies required, the terrain corrections to a radius of 16.6 meters for the stations used in profile 1 (stations g4 and g7 through g12) vary from a low of $0.8 \mu \mathrm{Gal}$ to a high of $10.8 \mu \mathrm{Gal}$ with an average of $5.9 \mu \mathrm{Gal}$, but given the gentle topography at the station locations the computed effect probably is accurate to better than $1 \mu \mathrm{Gal}$. The observed gravity for these stations have an average range of $6.7 \mu \mathrm{Gal}$ (Appendix B) and a standard deviation of $\pm 1.9 \mu \mathrm{Gal}$. The terrain correction, which drives the density determination via the gravity effect of the cylindrical model, is not very large in relation to the probable error in the observed gravity.

The final selection of the appropriate density for the terrace gravel model was via inspection of the landfill area terrace residual gravity in contour form for densities $1.50 \mathrm{gm} / \mathrm{cc}$ to $2.10 \mathrm{gm} / \mathrm{cc}$ at intervals of $0.1 \mathrm{gm} / \mathrm{cc}$. In general, the contours of figure 5 straightened until a reversal of overall curvature was noted at the lower densities. The density at which the contours contained the least information (the smoothest and straightest) is $1.8 \mathrm{gm} / \mathrm{cc}$, and the resulting gravity contours can be seen on figure 10 .

\section{Local trend removal from the terrace residual gravity}

The terrace residual gravity on figure 10 is the result of removing the overcorrection by the standard terrain model, but while the obvious dependence on local topography has been removed, the north-south trend of the regional residual gravity remains.

Examination of the contour spacing on figure 4 reveals no obvious slope breaks near the landfill upon which to base an estimate of the deeper structures of the Hartville uplift. The simplest structural model that produces a planar gravity field is a plane but one with any of a wide range of density contrast and slope. Therefore, a plane with a slope of $6.0 \mathrm{mGal} / \mathrm{km}$ north was removed from the terrace residual gravity with the understanding there is no particular deep structural information implied. 
The de-trending plane was fit in the north-south direction by observation of the average gravity values near stations g06 and g42, and when it is subtracted from the terrace residual gravity, the near-surface gravity anomalies remain (fig. 11). The specific value of slope and direction is somewhat arbitrary, and small variations produce similar results. Secondary east-west slopes on the order of $0.5 \mathrm{mGal} / \mathrm{km}$ were examined and discarded for lack of constraints.

\section{De-trended terrace residual gravity interpretation}

The de-trended gravity was produced by removal of known gravity effects, including deep-seated structures and the effect of the most shallow source (the topographic surface). The most striking of the resulting anomalies is an elongate low that is centered to the northwest of the mapped landfill cell along profile 1 and an elongate high that starts in the southwest corner at station g43, is most prominent up on the terrace near station g29, extends down into the ravine at station g20, and continues up onto the terrace at station $\mathrm{g} 40$. The relative difference in gravity between the low over profile 1 and the high on the terrace to the south remains a fairly constant $1 \mathrm{mGal}$ for a variety of terrace gravity densities and de-trending planes. In addition, the low along profile 1 remains north of station g52 (the center of the landfill cell) for all tested de-trending planes.

Station g52 is located in the center of the largest landfill cell (outlined on figure 11) and, in that position, is sensitive to a change of gravity caused by the addition of waste material and the disturbance of the soil. As can be seen on figure 11, the low gravity value in the area is near the intersection of profiles 1 and 2, and there is no distortion of the low that tends to follow the outline of the cell. A cylindrical model of the landfill cell 50 meters in radius, 8 meters thick and a relatively high density contrast of $-0.2 \mathrm{gm} / \mathrm{cc}$ with respect to the terrace gravel generates a gravity effect of only $-62 \mu \mathrm{Gal}$, far less than that necessary to explain the $1 \mathrm{mGal}$ anomaly. In addition, profile 3 crosses several minor ravines as determined from examination of the pre-landfill topographic map, but the gravity shows no indication of variation caused by density changes. From this, it may be supposed that compacted native fill dirt with a minor amount of landfill debris has about the same density as the undisturbed soil.

The data now have two density datums: the local $1.80 \mathrm{gm} / \mathrm{cc}$ layer above altitude 1,323 meters (NAD83 vertical) caused by the addition of the 3D terrace model, continuing with the standard $2.67 \mathrm{gm} / \mathrm{cc}$ model down to the ellipsoid. Further structural modeling across the 1323 meter boundary is most easily performed using a single density datum so a model body has a single density contrast. Provided the bottom of the terrace model is level and uninterrupted to a distance sufficient to minimize edge effects, approximately five times the model depth, the density reference below 1323 meters can be changed to $1.80 \mathrm{gm} / \mathrm{cc}$ and the resulting constant change in the gravity added to the regional field.

A 2.5D model was constructed with SAKI (Webring, 1985) along profile 2 and can be seen on figure 12. The top panel has the de-trended gravity values in red and the computed response of the model as a black line. The structural model in the bottom panel plots the gravity station locations and two layers or bodies without vertical exaggeration. 
The density reference for the model is $1.80 \mathrm{gm} / \mathrm{cc}$ so the terrace gravels have a density contrast of $0.0 \mathrm{gm} / \mathrm{cc}$ and contribute no effect and are, therefore, not enclosed in a body.

The thin area between the two undulating lines is body 1 and is interpreted to be a combination of Hartville limestone and metabasalt with a density contrast of $0.87 \mathrm{gm} / \mathrm{cc}$ $(2.67 \mathrm{gm} / \mathrm{cc}$ real density). Below this layer is body 2 that is interpreted as metadolomite with a density contrast of $1.02 \mathrm{gm} / \mathrm{cc}(2.82 \mathrm{gm} / \mathrm{cc}$ real density). The bottom of body 2 extends below the area of the panel to an arbitrary constant depth, and because it is level, does not contribute to the lateral variation of the gravity response. Both bodies extend to the south and north about 1 kilometer to minimize edge effects. The bodies extend 100 meters at 90 degrees from the strike of the profile. The calculated gravity effect floats to minimize the difference with respect to the observed gravity to compensate for deepseated mass that is not being modeled.

The Hartville formation is included in the model, because it outcrops near station g20 at distance coordinate 80,440 meters and is modeled as continuing west of the outcrop under profile 2 at approximately the same altitude as the outcrop. The Hartville layer, body 1 , is modeled as being continuous with a thickness of about 10 meters. This is an assumption that is not constrained by the gravity data, and the layer is shown as continuous based on the observation that there are no major discontinuities in the gravity field. The metadolomite layer, body 2 , can be used alone to fit the gravity field, in which case it would occupy some fraction of the thickness now shown as Hartville.

Once the basic model on figure 12 was fit to the de-trended terrace residual gravity, another possible constraint became apparent. The first model had the Hartville at a depth of approximately 30 meters below the surface at station g06 on the north end near coordinate 81,000 meters. The model was brought to about 15 meters below the surface to match the depth at station g20. The trend of the gravity then was recomputed to fit the model, and the end result is the $6.0 \mathrm{mGal} / \mathrm{km}$ de-trending surface could be reduced to $4.9 \mathrm{mGal} / \mathrm{km}$. The model was reconverged, and the final result is shown on figure 12 . In other words, the original assumption that the entire trend was deep seated could be modified by assigning some of the trend to the top surface of the basement formations.

The relief in the hard-rock layers between distance coordinates 80,440 and 80,700 meters is about 30 meters and, as has been mentioned is not too dependent on the specific composition of the layer or the details of de-trending. For example, the initial model fit to the $6.0 \mathrm{mGal} / \mathrm{km}$ de-trend data had the same overall basement relief as the reconverged model using $4.9 \mathrm{mGal} / \mathrm{km}$ de-trend data.

The model described in the preceding sections is relatively simple, and the interpretation must likewise be hedged with regard to the possible features that are simplified. In particular, the east-west extent of these features is not well constrained. The north-south direction has more stations but, in that direction, is the major gradient which does not have any major slope breaks to help define the deep-seated causative bodies. The outcrop near station g20 is assumed to be in place, which then fixes the altitude of the 
basement model at one point. The assumption that the basement remains shallow to the north helps define the range of probable trend surfaces.

\section{Conclusions}

The Bouguer anomaly on figure 4 shows a south to north increase of about $9 \mathrm{mGal}$, increasing in slope to the north toward the presumed core of the Hartville Uplift. Stations to the east and west of the cross-valley profile indicate the slope of the gravity field is almost due north-south. The interpreted dip of the basement and(or) thickening of the North Platte River sediments then would be approximately due south.

The residual Bouguer anomaly around the landfill (fig. 5) shows a high-low pair defined by the north-south profile 2 , the southeast portion of profile 3 and the outlying perimeter stations. While station g20 (southeast of the junction of profiles 1 and 3) appears to be causing a one-station anomaly, the overall trend of profile 3 tends to confirm that there is a local high-density structure to the southeast of the landfill cells outlined in red.

The gravity anomaly values of the southwest to northeast profile 3 vary smoothly. This profile crosses several minor ravines, as determined from examination of the old topographic surface, but is now a smooth dirt road. From this, it may be supposed that compacted landfill debris combined with fill dirt has about the same density as the undisturbed terrace gravels. In addition, a simple cylindrical model of the estimated dimensions of the cell beneath station g52 would only generate a fraction of the effect seen between profile 1 and the south end of profile 2 .

Modeling of the terrace gravels using a density of $1.80 \mathrm{gm} / \mathrm{cc}$ removes some obvious terrain effects and leaves a predominantly northward increasing gravity field. A planar fit to this trend reveals anomalies with strong east-west elongation that are stable with respect to small variations of the plane. Further 2.5-D modeling of the terrace residual gravity indicates 30 meters of basement relief with the low area to the north of the landfill cells and the high area on the south boundary of the landfill.

\section{Data availability}

This report, the gravity and surveying data sets are available as separate files located on greenwood.cr.usgs.gov. 


\section{Figure credits}

- Digital Line Graphics (DLG) file of roads on figure 1 were acquired from the USGS/EROS Data Center, Sioux Falls, S. Dakota.

- Digital Exchange Format (DXF) file of landfill features on figures 1, 2, 3, 4, 5, 10, 11 were acquired from the USGS/Water Resources Division, Cheyenne, Wyoming.

- Digital Elevation Model (DEM) files of topographic data on figures 1 and 2 were acquired from the USGS/EROS Data Center.

\section{References}

Chapman, M.E., and Bodine, J.H., 1979, Considerations of the indirect effect in marine Gravity modeling: Journal of Geophysical Research, v. 84, p. 3889-3892.

Hammer, S., 1939, Terrain corrections for gravimeter stations: Geophysics, v. 4, p. 184-194.

Harris, R.E., 1997, Preliminary geologic map of the Guernsey quadrangle, Platte and Goshen counties, Wyoming: U.S. Geological Survey Map 97-1.

Hayford, J.F. and Bowie, W., 1912, The effect of topography and isostatic compensation upon the intensity of gravity: Coast and Geodetic Survey Special Publication no. 10 .

Heiskanen, W.A., Moritz, H., 1969, Physical Geodesy, W.H. Freeman Co.

Hinze, W.J., 2003, Bouguer reduction density, why 267?: Geophysics, v. 68, no. 5, p. $1559-1560$.

LaFehr, T.R., 1991, An exact solution for the gravity curvature (Bullard B) correction, Geophysics, v. 56, p. 1170-1178.

Li, X., and Götze, H.-J., 2001, Tutorial: Ellipsoid, geoid, gravity, geodesy, and Geophysics: Geophysics, v. 66, no. 1, p. 660-668.

Longman, I.M., 1959, Formulas for computing the tidal acceleration due to the moon and sun: Journal of Geophysical Research, v. 64, no. 12, p. 2351-2355.

McDougal, R.R., Abraham J.D., and Bisdorf, R.J., 2004, Results of electrical resistivity Data collected near the town of Guernsey, Platte County, Wyoming: U. S. Geological Survey Open-File Report 2004-1095.

Morelli, C., (ed.), 1974, The International Gravity Standardization Net 1971: International Assn. Geod. Spec. Publ. 4. 
Moritz, H., 1980, Geodetic Reference System 1980, Bulletin Geodesique, v. 54, no. 3 , p. 395-405.

Nettleton, L.L., 1939, Determination of density for reduction of gravimeter observations: Geophysics, v. 4, p. 176-183.

Plouff, D., 1977, Preliminary documentation for a FORTRAN program to compute gravity terrain corrections based on topography digitized on a geographic grid: U.S. Geological Survey Open-File Report 77-535, 45 p.

Smith, D.A., and Roman, D.R., 2001, GEOID99 and G99SSS: 1-arc-minute geoid Models for the United States: Journal of Geodesy, v. 75, p. 469-490.

Smith, W.H.F., and Wessel, P., 1990, Gridding with continuous splines in tension: Geophysics, v. 55, no. 3, p. 293-305.

Webring, M.W., 1981, MINC: a gridding program based on minimum curvature: U.S. Geological Survey Open-File Report 81-1224.

Webring, M.W., 1985, SAKI: A Fortran program for generalized linear inversion of gravity and magnetic profiles: U.S. Geological Survey Open-File Report 85-122. 


\section{$\underline{\text { Appendix }} \underline{\mathbf{A}}$}

\section{Principal facts for the Guernsey landfill gravity survey:}

station - gravity station ID

longitude - NAD83 datum in decimal degrees

latitude - NAD83 datum in decimal degrees

elevation - NAD83 datum, ellipsoidal height in meters

obsgrv - observed gravity relative to IGSN71

itc - inner terrain correction (zones A-H) at $2.67 \mathrm{gm} / \mathrm{cc}$

otc - outer terrain correction (zones I-O) at $2.67 \mathrm{gm} / \mathrm{cc}$

faa - free air anomaly, referred to ellipsoidal height

ba - Bouguer anomaly referred to ellipsoidal height, reduction density $2.67 \mathrm{gm} / \mathrm{cc}$ (proposed name: ellipsoidal Bouguer anomaly, NAGDB committee, 2003)

\begin{tabular}{|c|c|c|c|c|c|c|c|c|}
\hline$n$ & $\begin{array}{l}\text { longitude } \\
\text { dec degree }\end{array}$ & $\begin{array}{c}\text { latitude } \\
\text { dec degree }\end{array}$ & $\begin{array}{c}\text { elevation } \\
\text { meter }\end{array}$ & $\begin{array}{l}\text { obsgrv } \\
\text { mGal }\end{array}$ & $\begin{array}{c}\text { itc } \\
\mathrm{mGal}\end{array}$ & $\begin{array}{l}\text { otc } \\
\text { mGal }\end{array}$ & $\begin{array}{l}\text { faa } \\
\text { mGal }\end{array}$ & $\begin{array}{l}\mathrm{ba} \\
\mathrm{mGal}\end{array}$ \\
\hline bh1 & -104.7466471 & 42.2694335 & 1310.089 & 979975.0075 & 0.1515 & -0.024 & 6.6847 & -16 \\
\hline bh2 & -104.7294881 & 42.2727569 & 1329.375 & 979972.9342 & 0.2021 & -0.061 & 10.2580 & .7423 \\
\hline bh3 & -104.7179542 & 42.2600324 & 1316.303 & 979970.3679 & 0.0372 & -0.069 & 4.8077 & -143.8952 \\
\hline bh4 & -104.7414126 & 42.2652887 & 1308.624 & 979973.4484 & 0.1159 & -0.033 & 5.0473 & -142.6771 \\
\hline bh5 & -104.7414843 & 42.2607775 & 1305.713 & 979972.4056 & 0.3472 & -0.032 & 3.5134 & -143.6513 \\
\hline bh6 & -104.7427084 & 42.2579626 & 1301.496 & 979972.6068 & 0.1309 & -0.026 & 2.6680 & -144.2326 \\
\hline bh7 & -104.7417840 & 42.2538060 & 1305.101 & 979971.2414 & 0.0801 & -0.039 & 2.7884 & -144.5815 \\
\hline bh8 & -104.7402831 & 42.2678780 & 1309.686 & 979974.3269 & 0.0584 & -0.031 & 6.0200 & -141.8793 \\
\hline bh9 & -104.7382304 & 42.2699783 & 1312.306 & 979974.6819 & 0.0629 & -0.034 & 6.9936 & -141.1990 \\
\hline bh1 & -104.7362703 & 42.2716287 & 1318.933 & 979974.2724 & 0.1520 & -0.044 & 8.4785 & -140.3803 \\
\hline bl & -104.7340465 & 42.2745282 & 1338.761 & 979972.1292 & 0.1160 & -0.065 & 12.1871 & -138.9589 \\
\hline g01 & -104.7422469 & 42.2787332 & 1350.343 & 979972.3490 & 0.1098 & -0.063 & 15.5988 & -136.8539 \\
\hline $\mathrm{g} 02$ & -104.7410960 & 42.2780578 & 1347.285 & 979972.4588 & 0.1087 & -0.063 & 14.8267 & -137.2832 \\
\hline $\mathrm{g} 03$ & -104.7379229 & 42.2793510 & 1349.371 & 979973.3697 & 0.1201 & -0.062 & 16.2642 & -136.0679 \\
\hline $\mathrm{g} 04$ & -104.7401129 & 42.2789204 & 1347.042 & 979973.2149 & 0.0983 & -0.061 & 15.4302 & -136.6608 \\
\hline g05 & -104.7441790 & 42.2787577 & 1344.866 & 979973.5931 & 0.1196 & -0.059 & 15.1522 & -136.6708 \\
\hline g06 & -104.7424152 & 42.2807802 & 1351.700 & 979973.9555 & 0.0879 & -0.061 & 17.4393 & -135.1859 \\
\hline g07 & -104.7404479 & 42.2788425 & 1346.794 & 979973.2301 & 0.1023 & -0.061 & 15.3759 & -136.6831 \\
\hline g08 & -104.7407943 & 42.2787618 & 1346.825 & 979973.1410 & 0.1011 & -0.061 & 15.3037 & -136.7601 \\
\hline g09 & -104.7411476 & 42.2786875 & 1348.367 & 979972.6999 & 0.0947 & -0.062 & 15.3446 & -136.8999 \\
\hline $\mathrm{g} 10$ & -104.7397649 & 42.2789245 & 1346.005 & 979973.4625 & 0.1103 & -0.060 & 15.3577 & -136.6036 \\
\hline g11 & -104.7393566 & 42.2790429 & 1345.238 & 979973.7754 & 0.1116 & -0.060 & 15.4235 & -136.4503 \\
\hline g12 & -104.7389987 & 42.2791162 & 1346.954 & 979973.5224 & 0.1054 & -0.061 & 15.6929 & -136.3810 \\
\hline g13 & -104.7386465 & 42.2791760 & 1347.686 & 979973.4792 & 0.1108 & -0.062 & 15.8700 & -136.2819 \\
\hline g14 & -104.7415104 & 42.2786706 & 1349.305 & 979972.5030 & 0.0997 & -0.063 & 15.4384 & -136.9076 \\
\hline g15 & -104.7418683 & 42.2786253 & 1349.866 & 979972.3600 & 0.1067 & -0.063 & 15.4725 & -136.9297 \\
\hline g16 & -104.7422308 & 42.2786135 & 1349.827 & 979972.3906 & 0.1091 & -0.063 & 15.4921 & -136.9032 \\
\hline
\end{tabular}


g17 $-104.7425978 \quad 42.2786111 \quad 1348.737 \quad 979972.6193$ g18 $-104.7382857 \quad 42.2792282 \quad 1348.777 \quad 979973.3144$ $\begin{array}{llllll}\text { g19 } & -104.7375622 & 42.2793894 & 1349.365 & 979973.4874\end{array}$ $\begin{array}{llllll}\text { g20 } & -104.7394102 & 42.2769132 & 1332.423 & 979975.6152\end{array}$ $\begin{array}{llllll}\text { g2 } 1 & -104.7405707 & 42.2762724 & 1342.433 & 979972.9954\end{array}$ g22 $\quad-104.7400425 \quad 42.2754573 \quad 1326.359 \quad 979975.6177$ g23 $-104.7401053 \quad 42.2755914 \quad 1327.792 \quad 979975.5352$ g24 $-104.7401566 \quad 42.2757141 \quad 1331.199 \quad 979974.9596$ $\begin{array}{llllll}\text { g25 } & -104.7402164 & 42.2758278 & 1336.771 & 979973.8140\end{array}$ g26 $-104.7402640 \quad 42.2759346 \quad 1341.418979972 .8742$ $\begin{array}{llllll}\text { g2 } 7 & -104.7402873 & 42.2760254 & 1342.472 & 979972.7595\end{array}$ $\begin{array}{llllll}\text { g2 } & -104.7403886 & 42.2761841 & 1342.291 & 979972.9731\end{array}$ $\begin{array}{llllll}\text { g29 } & -104.7404685 & 42.2763061 & 1342.417 & 979973.0438\end{array}$ g30 $-104.7405576 \quad 42.2765695 \quad 1342.948 \quad 979973.0817$ g31 $-104.7406484 \quad 42.2768297 \quad 1343.531979973 .0300$ g32 $104.7407187 \quad 42.2770832 \quad 1342.830 \quad 979973.2564$ g33 $-104.7408461 \quad 42.2773425 \quad 1344.402 \quad 979972.9765$ g34 $-104.7409388 \quad 42.2776004 \quad 1345.737 \quad 979972.7446$ $\begin{array}{llllll}\text { g35 } & -104.7410317 & 42.2778610 & 1346.285 & 979972.6499\end{array}$ g36 $-104.7411106 \quad 42.2781223 \quad 1347.080 \quad 979972.5271$ g37 $-104.7411936 \quad 42.2783811 \quad 1347.736 \quad 979972.5633$ $\begin{array}{llllll}\text { g38 } & -104.7395122 & 42.2778285 & 1339.404 & 979974.3629\end{array}$ $\begin{array}{llllll}\text { g39 } & -104.7391435 & 42.2807764 & 1355.565 & 979973.4818\end{array}$ $\begin{array}{llllll}\text { g40 } & -104.7377617 & 42.2774699 & 1345.549 & 979973.1501\end{array}$ g41 $-104.7391682 \quad 42.2744566 \quad 1323.989 \quad 979975.1210$ $\begin{array}{llllll}\text { g42 } & -104.7407200 & 42.2747922 & 1323.452 & 979975.8407\end{array}$ g43 $-104.7432873 \quad 42.2755470 \quad 1325.917 \quad 979975.6922$ $\begin{array}{llllll}\text { g44 } & -104.7398008 & 42.2776660 & 1339.737 & 979974.1958\end{array}$ $\begin{array}{llllll}\text { g45 } & -104.7400875 & 42.2775000 & 1340.979 & 979973.8450\end{array}$ g46 $-104.7404157 \quad 42.2773916 \quad 1343.469 \quad 979973.2428$ $\begin{array}{llllll}\text { g47 } & -104.7393539 & 42.2780719 & 1339.781 & 979974.3736\end{array}$ g48 $-104.7390873 \quad 42.2783175 \quad 1339.062 \quad 979974.6325$ $\begin{array}{llllll}\text { g49 } & -104.7385917 & 42.2788490 & 1346.291 & 979973.4657\end{array}$ $\begin{array}{llllll}\text { g50 } & -104.7387593 & 42.2797355 & 1352.441 & 979973.0073\end{array}$ g51 $-104.7389856 \quad 42.2802896 \quad 1352.834979973 .5698$ $\begin{array}{llllll}\text { g55 } & -104.7404677 & 42.2783780 & 1349.780 & 979972.1648\end{array}$
0.1087 0.1112 0.1238 0.1907 0.1823 0.1469 0.1751 0.2240 0.2803 0.3366 0.2907 0.2124 0.1843 0.1565 0.1358 0.1137 0.1120 0.1118 0.1101 0.1053 0.0979 0.1101 0.1021 0.1136 0.1266 0.1031 0.1316 0.1099 0.1105 0.1116 0.1159 0.1357 $\begin{array}{lllll}0.1177 & -0.061 & 15.4559 & -136.5312\end{array}$ $\begin{array}{llll}0.1126 & -0.063 & 16.8136 & -135.8722\end{array}$ $\begin{array}{lllll}0.1065 & -0.062 & 17.4474 & -135.2877\end{array}$ $\begin{array}{lllll}0.1207 & -0.064 & 15.2730 & -137.1064\end{array}$ 


\section{$\underline{\text { Appendix }} \underline{B}$}

The following is a list of stations, the number of readings for the station, and the range of gravity readings for the station. Some stations have ranges larger than the target of about $10 \mu \mathrm{Gal}$ and, where feasible, the extreme reading is deleted and a new range is given in the comment field.

Two days, July 12 and 13, consistently yielded either the maximum or minimum value, and so these days were deleted entirely. This procedure leaves two stations, g34 and g35, without a repeat but given the range was less than $19 \mu \mathrm{Gal}$, the remaining value likely is accurate to within the desired limits. Examination of the data in profile form confirms this expectation.

The statistics for the revised data are then:

number of samples $=46$

maximum range $\quad=14.4 \mu \mathrm{Gal}$

average range $\quad=5.93 \mu \mathrm{Gal}$

standard deviation $=4.11 \mu \mathrm{Gal}$.

The overall accuracy of the relative gravity values can be stated as: $95.5 \%$ of the time ( 2 standard deviations) the range of repeated reading will fall between 0 and $14.15 \mu \mathrm{Gal}$. A $95.5 \%$ confidence level is then about $+/-7 \mu \mathrm{Gal}$. Averaging multiple readings further decreases the error.

The tie between g01 and g21 (primary and secondary bases), without deletion of two July 12 readings, has a range of $11.9 \mu \mathrm{Gal}$ and a standard deviation of $4.7 \mu \mathrm{Gal}$. Deleting the July 12 readings yields a range of $5.1 \mu \mathrm{Gal}$ and a standard deviation of $2.2 \mu \mathrm{Gal}$.

\section{station number of \\ id readings}

$\begin{array}{llr}\text { bh1 } & 3 & 12.3 \\ \text { bh2 } & 1 & \text { na } \\ \text { bh3 } & 1 & \text { na } \\ & & \\ \text { bh4 } & 2 & 3.8 \\ \text { bh5 } & 2 & 1.5 \\ \text { bh6 } & 2 & 0.2 \\ \text { bh7 } & 2 & 2.2 \\ \text { bh8 } & 1 & \text { na } \\ \text { bh9 } & 1 & \text { na } \\ \text { bh10 } & 1 & \text { na } \\ \text { bh11 } & 1 & \text { na } \\ \text { g01 } & 3 & 12.3\end{array}$

2.3

na

na

3.8

.5

0.2

na

na

na comments

$\mu \mathrm{Gal}$

12.3 Primary base for landfill survey
Tied to $\mathrm{g} 1$ and Wheatland base. Benchmark(BM) 4408 (southeast of landfill) BM Z-63, reference mark for all position surveying.

BM 4340 (in Guernsey) 


\begin{tabular}{|c|c|c|c|}
\hline g02 & 3 & 9.1 & \\
\hline g03 & 3 & 16.5 & Remove minimum, new range 0.1 \\
\hline g04 & 2 & 3.2 & \\
\hline g05 & 3 & 3.7 & \\
\hline g06 & 4 & 22.5 & Remove both high and low, new range 11.7 \\
\hline g07 & 3 & 11.1 & \\
\hline g08 & 2 & 2.2 & \\
\hline g09 & 2 & 6.4 & \\
\hline $\mathrm{g} 10$ & 3 & 10.3 & \\
\hline g11 & 3 & 9.8 & \\
\hline g12 & 2 & 3.8 & \\
\hline g13 & 3 & 15.3 & Remove(Rm) max value, new range 3.1 \\
\hline g14 & 2 & 1.7 & \\
\hline g15 & 2 & 11.0 & \\
\hline g16 & 2 & 7.2 & \\
\hline g17 & 2 & 2.1 & \\
\hline g18 & 3 & 14.4 & \\
\hline g19 & 2 & 10.8 & \\
\hline g20 & 2 & 1.4 & \\
\hline g21 & 7 & 11.9 & $\begin{array}{l}\text { Secondary landfill base, removing two July } \\
12 \text { readings lowers range to } 5.1\end{array}$ \\
\hline g22 & 3 & 16.0 & $\mathrm{Rm} 7 / 12$ max, new range 1.6 \\
\hline g23 & 2 & 2.2 & $\mathrm{Rm} 7 / 12$ min, no range \\
\hline g24 & 3 & 10.4 & $\mathrm{Rm} 7 / 12$ max, new range 4.2 \\
\hline g25 & 2 & 3.0 & $\mathrm{Rm} 7 / 12$ max, no range \\
\hline g26 & 3 & 2.7 & $\mathrm{Rm} 7 / 12$ min, no change in range \\
\hline g27 & 4 & 37.3 & $\mathrm{Rm} 7 / 12 \mathrm{~min}$, and the max, new range 6.1 \\
\hline g28 & 3 & 16.7 & $\mathrm{Rm} 7 / 12$ min, new range 4.8 \\
\hline g29 & 3 & 13.2 & $\mathrm{Rm} 7 / 12$ min, new range 2.4 \\
\hline g30 & 3 & 2.8 & $\mathrm{Rm} 7 / 13$ max, new range 0.5 \\
\hline g31 & 3 & 16.0 & $\mathrm{Rm} 7 / 13$ max, new range 6.3 \\
\hline g32 & 3 & 17.3 & $\mathrm{Rm} 7 / 13$ max, new range 4.1 \\
\hline g33 & 3 & 18.8 & $\mathrm{Rm} 7 / 13$ max, new range 4.1 \\
\hline g34 & 2 & 18.6 & $\mathrm{Rm} 7 / 13$ min, no range \\
\hline g35 & 2 & 15.5 & $\mathrm{Rm} 7 / 13$ min, no range \\
\hline g36 & 2 & 8.6 & \\
\hline g37 & 2 & 9.0 & \\
\hline g38 & 2 & 0.4 & \\
\hline g39 & 1 & na & \\
\hline g40 & 1 & na & \\
\hline g41 & 1 & na & \\
\hline g42 & 1 & na & \\
\hline g43 & 1 & na & \\
\hline g44 & 2 & 11.0 & \\
\hline g45 & 2 & 2.2 & \\
\hline g46 & 2 & 8.0 & \\
\hline
\end{tabular}




$\begin{array}{llcl}\text { g47 } & 2 & 12.9 & \\ \text { g48 } & 3 & 26.5 & \text { Remove minimum, new range 10.6 } \\ \text { g49 } & 2 & 11.3 & \\ \text { g50 } & 2 & 10.1 & \\ \text { g51 } & 1 & \text { na } & \\ \text { g52 } & 2 & 3.5 & \end{array}$




\section{$\underline{\text { Appendix }} \underline{\mathrm{C}}$}

Benchmark data sheets are available at http://www.ngs.noaa.gov.

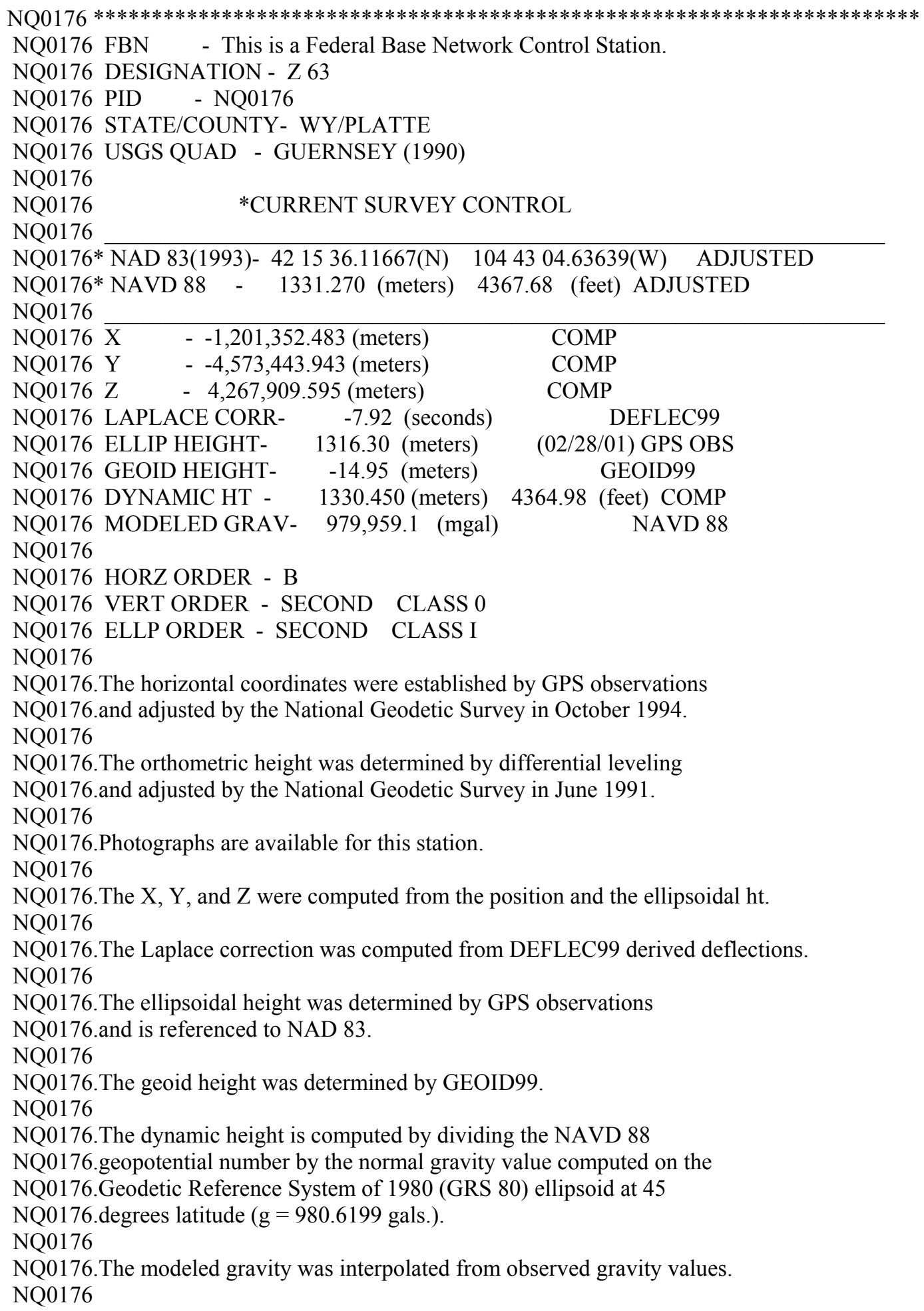




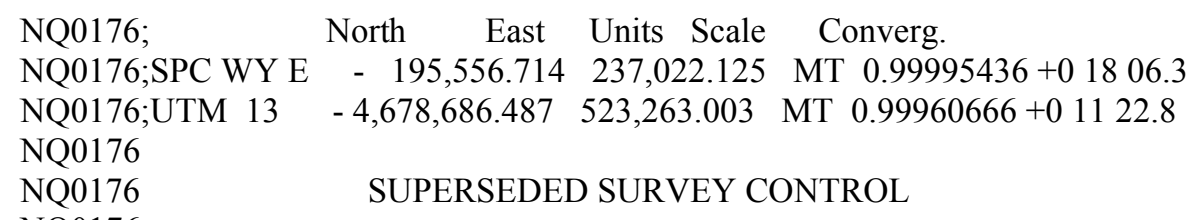


NQ0176'STATION MARK IS A DISK SET IN THE TOP OF A 15-CM SQUARE CONCRETE POST NQ0176'PROJECTING 15 CM ABOVE GROUND. IT IS 37.2 M (122.0 FT) NORTHEAST OF, NQ0176'AND 3 M (9.8 FT) LOWER THAN THE ROAD CENTER, 7.5 M (24.6 FT) SOUTH OF NQ0176'THE SOUTH RAIL OF RAILROAD TRACK, 4.9 M (16.1 FT) WEST OF A TELEPHONE NQ0176'POLE, 28.7 M (94.2 FT) SOUTHEAST OF A TELEPHONE POLE, AND 0.3 M (1.0 NQ0176'FT) NORTHEAST OF A METAL WITNESS POST. DESCRIBED BY WTD, TYPED BY GRH.

NQ0176

NQ0176

NQ0176

STATION RECOVERY (1999)

NQ0176'RECOVERY NOTE BY NATIONAL GEODETIC SURVEY 1999 (CSM)

NQ0176'RECOVERED BY NATIONAL GEODETIC SURVEY 1999. RECOVERED IN GOOD

NQ0176'CONDITION, NEW DESCRIPTION FOLLOWS. THE STATION IS LOCATED ABOUT 3.14

NQ0176'KM (1.95 MI) EAST-SOUTHEAST OF GUERNSEY, $0.97 \mathrm{KM}$ (0.60 MI) SOUTHEAST

NQ0176'OF THE ENTRANCE ROAD OF THE GUERNSEY AIRPORT, ON THE SOUTH SIDE OF

THE

NQ0176'BURLINGTON NORTHERN AND SANTA FE RAILROAD TRACKS.

NQ0176'OWNERSHIP--BURLINGTON NORTHERN AND SANTA FE RAILWAY COMPANY, 100

NQ0176'CEMETERY ROAD, GUERNEY, WY 82214. CONTACT STEVE KETCHUM PHONE

NQ0176'307-836-5200. NOTE--MUST HAVE REQUIRED OSHA APPROVED SAFETY GLASSES

NQ0176'WITH SIDE SHIELDS, HARD HAT AND ABOVE THE ANKLE SAFETY TOE BOOTS TO

NQ0176'ACCESS THE SITE. TO REACH THE STATION FROM THE EAST END OF THE US

NQ0176'HIGHWAY 26 BRIDGE OVER THE NORTH PLATTE RIVER ON THE WEST SIDE OF

NQ0176'GUERNSEY, GO EAST ON HIGHWAY 26 (WHALEN STREET) FOR 2.01 KM (1.25 MI)

NQ0176'TO A PAVED ROAD RIGHT (AT SIGN--AIRPORT AND JUST PAST HIGHWAY

MILEPOST

NQ0176'16), TURN RIGHT AND GO SOUTH THEN EAST ON THE ROAD FOR 0.16 KM (0.10

NQ0176'MI) TO THE ENTRANCE ROAD TO THE AIRPORT ON THE RIGHT, CONTINUE AHEAD

NQ0176'EAST ON THE ROAD FOR 0.97 KM (0.60 MI) TO THE STATION ON THE RIGHT.

NQ0176'FROM THIS POINT PACK ABOUT 30.48 M (100.00 FT) DOWNHILL TO THE STATION

NQ0176'ON THE SOUTH SIDE OF THE RAILROAD TRACKS. THE STATION IS AN CGS BENCH

NQ0176'MARK DISK SET IN THE TOP OF 15 CM SQUARE CONCRETE POST ABOUT FLUSH

NQ0176'WITH THE GROUND, 3.06 M (10.04 FT) LOWER THAN THE ROAD AND 0.3 M (1.0

NQ0176'FT) LOWER THAN THE TRACKS. IT IS, 37.2 M (122.0 FT) NORTH OF THE

NQ0176'CENTER OF THE ROAD, 7.5 M (24.6 FT) SOUTH OF THE SOUTH RAIL OF THE

NQ0176'TRACKS, 0.3 M (1.0 FT) WEST OF AN NGS FIBERGLASS WITNESS POST AND 0.77

NQ0176'M (2.53 FT) WEST OF A WYDOT FIBERGLASS WITNESS POST AND SURROUNDED BY

NQ0176'3 4X4 WOOD POSTS PROJECTING ABOUT 0.77 M (2.53 FT) ABOVE THE GROUND.

NQ0176'DESCRIBED BY M.L. MCCREADY WITH NOTES BY R.G. BAILEY. 


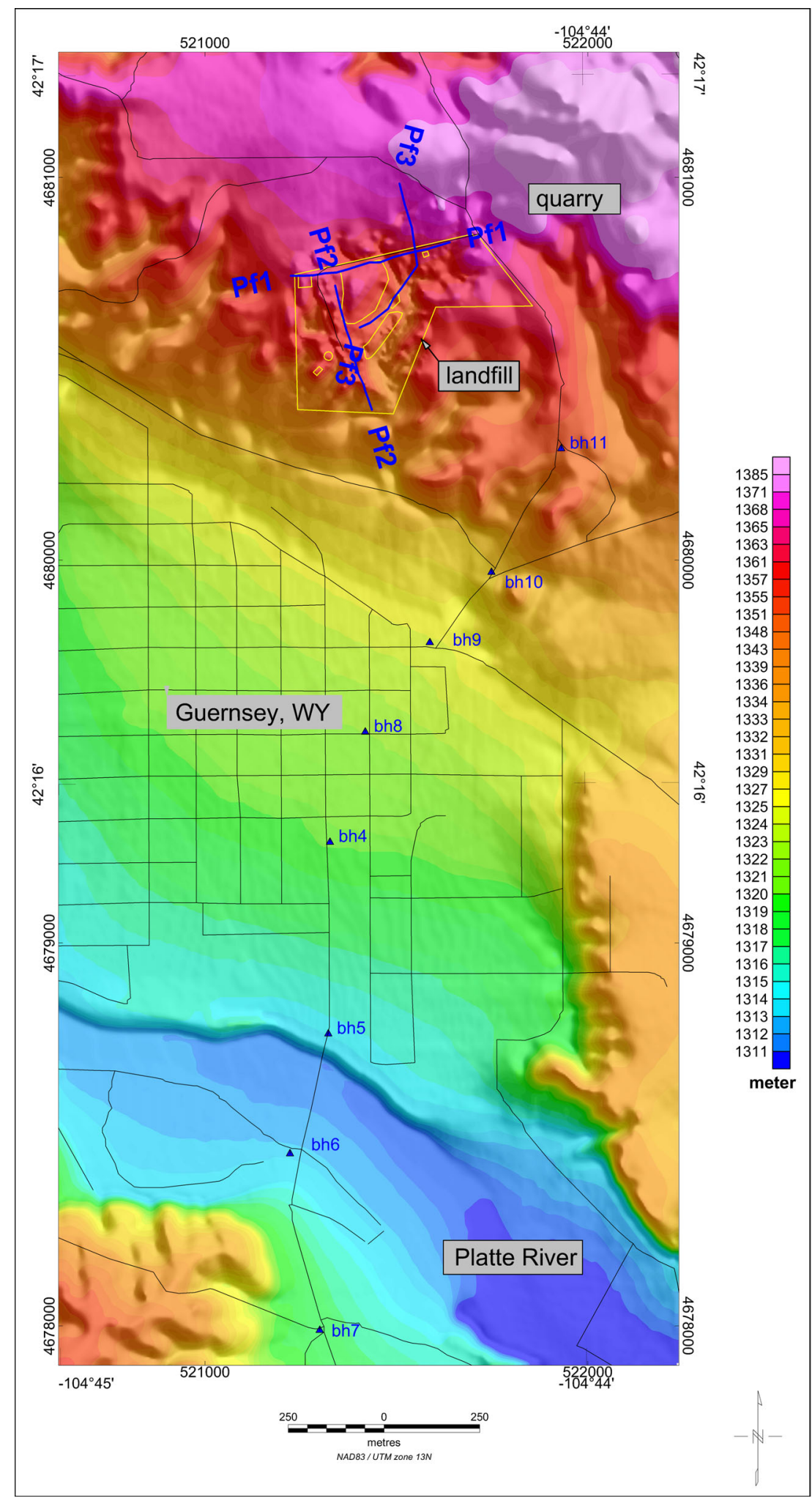

figure 1. Topography of Guernsey and landfill at 5-meter resolution with gravity profiles and landfill features superimposed. 

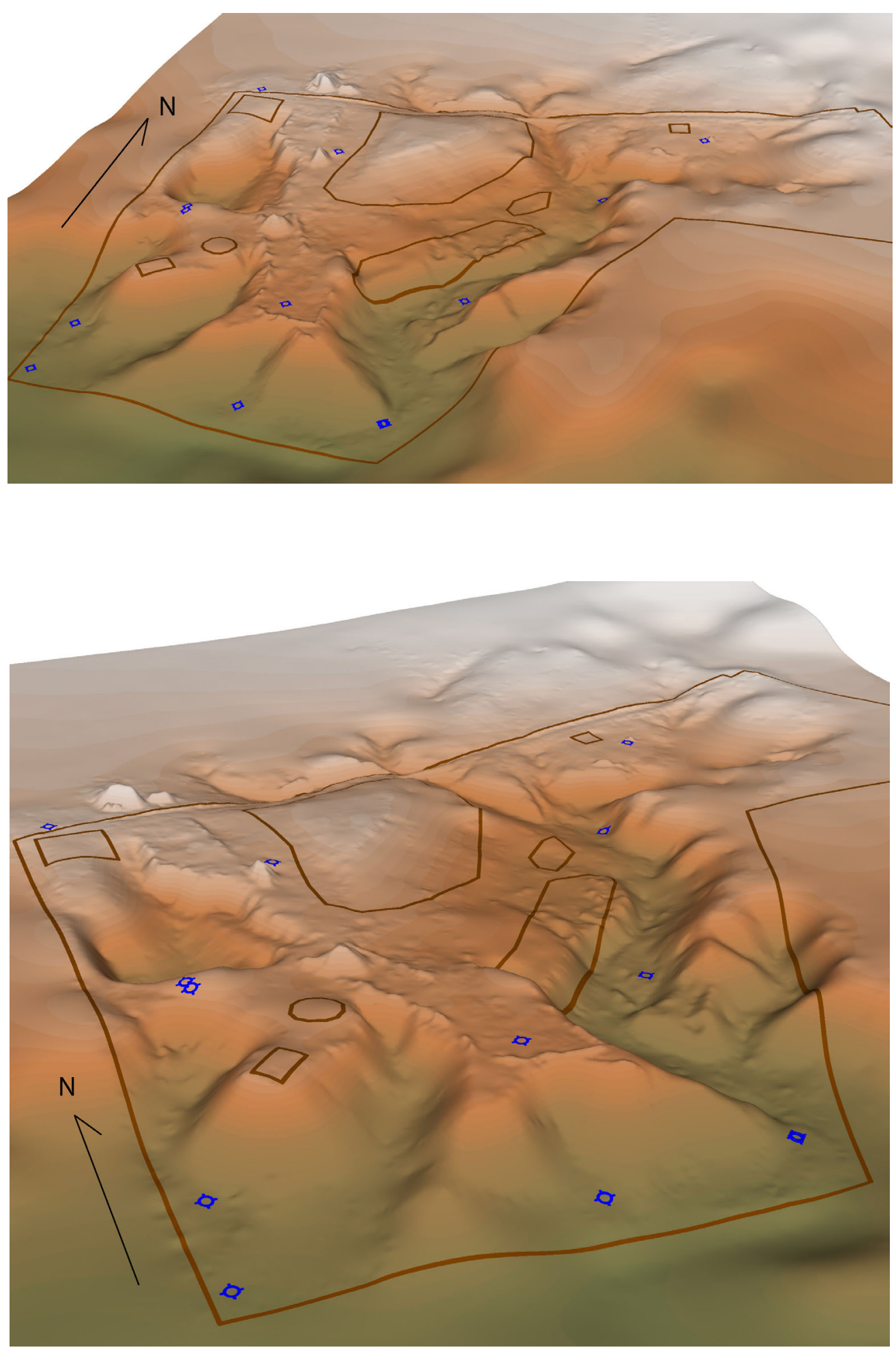

figure 2. Shaded-relief maps of topography from real-time kinematic GPS survey combined with DEM 10-meter data. Vertical exaggeration is $2 \mathrm{X}$. Brown lines define landfill boundary and key features. Blue circles indicate well locations. 


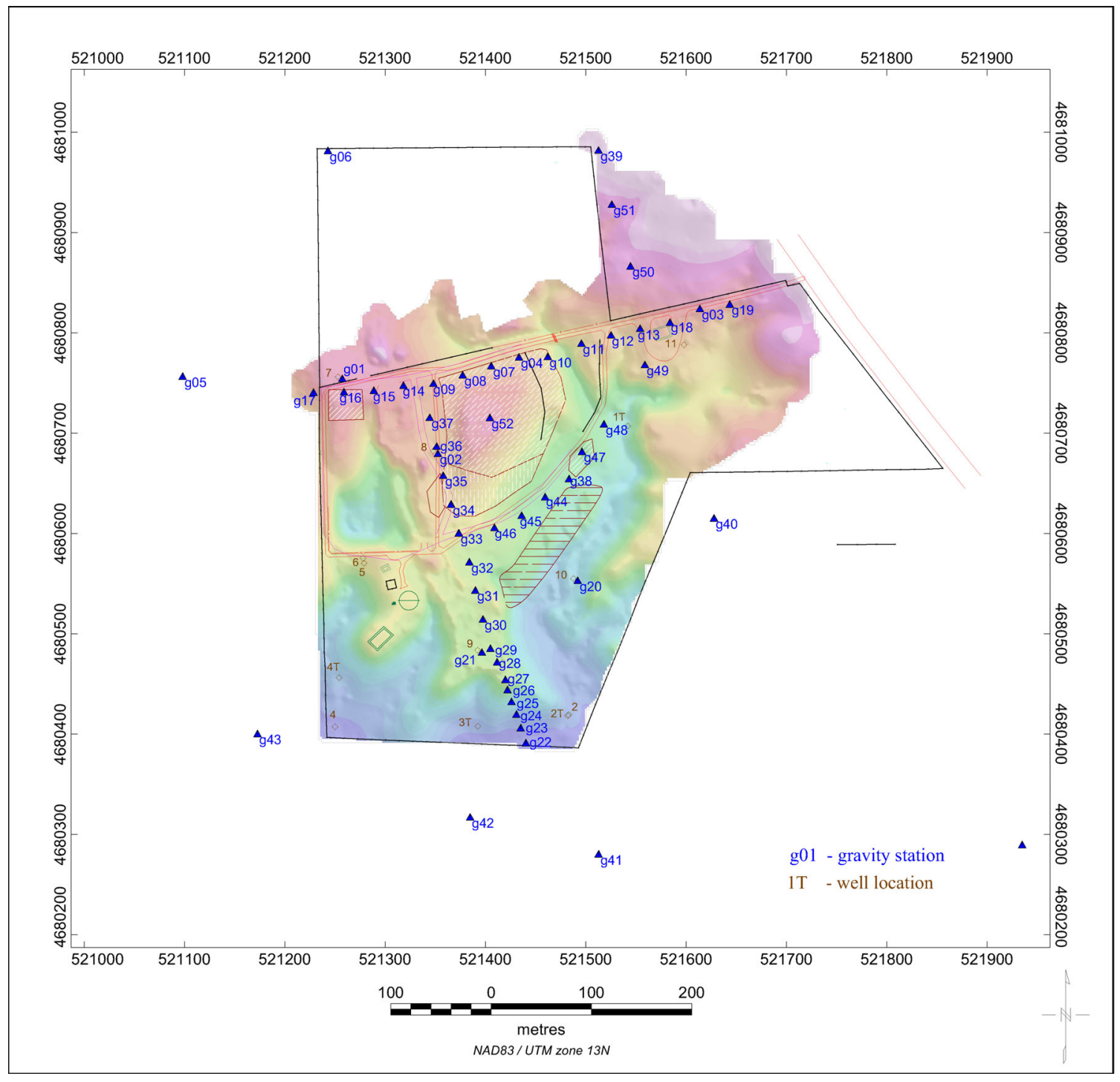

figure 3. Site map of Guernsey landfill showing placement of gravity stations superimposed over 2-meter resolution shaded-relief topography. 


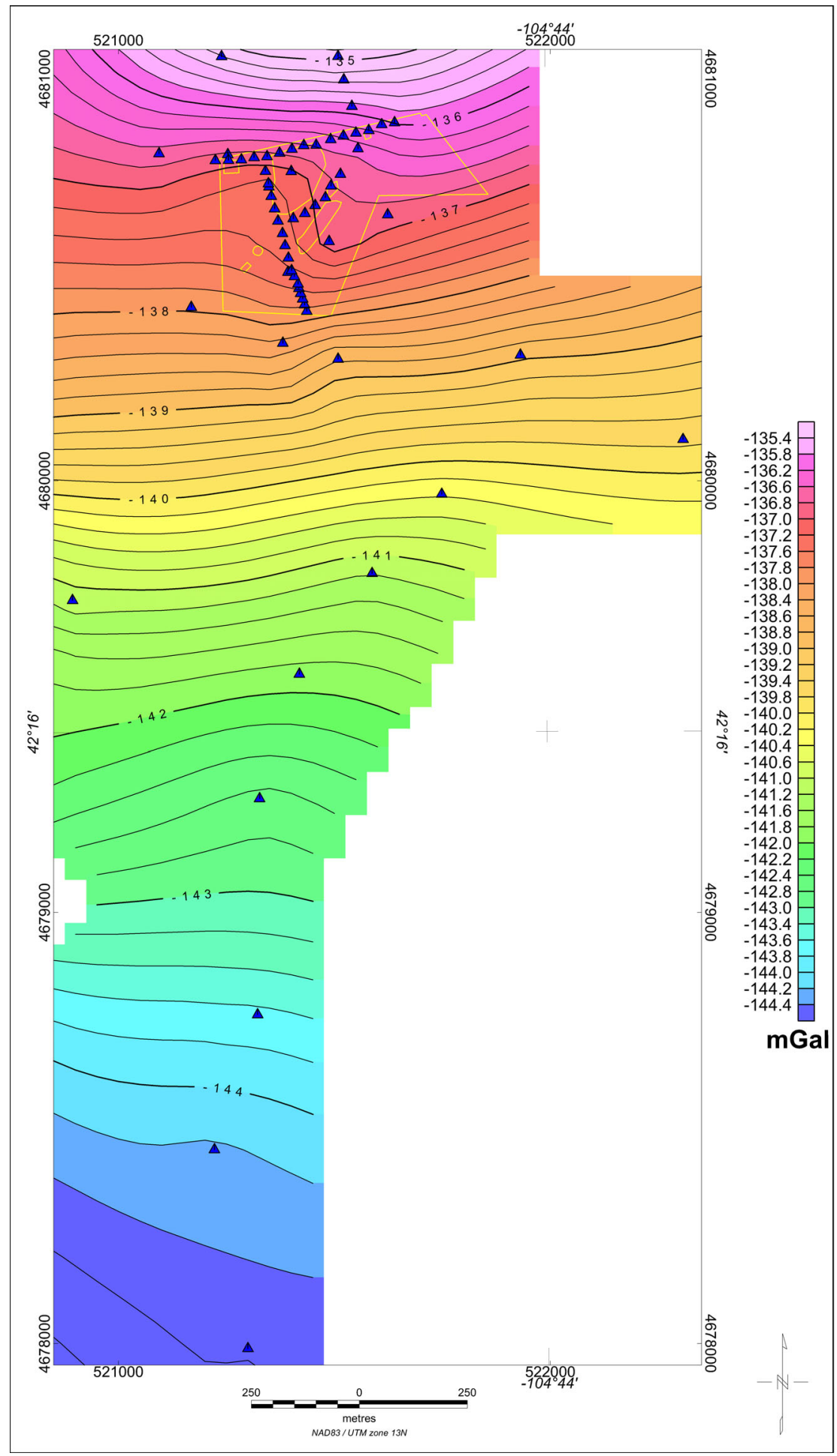

figure 4. Bouguer gravity anomaly with station locations superimposed. 


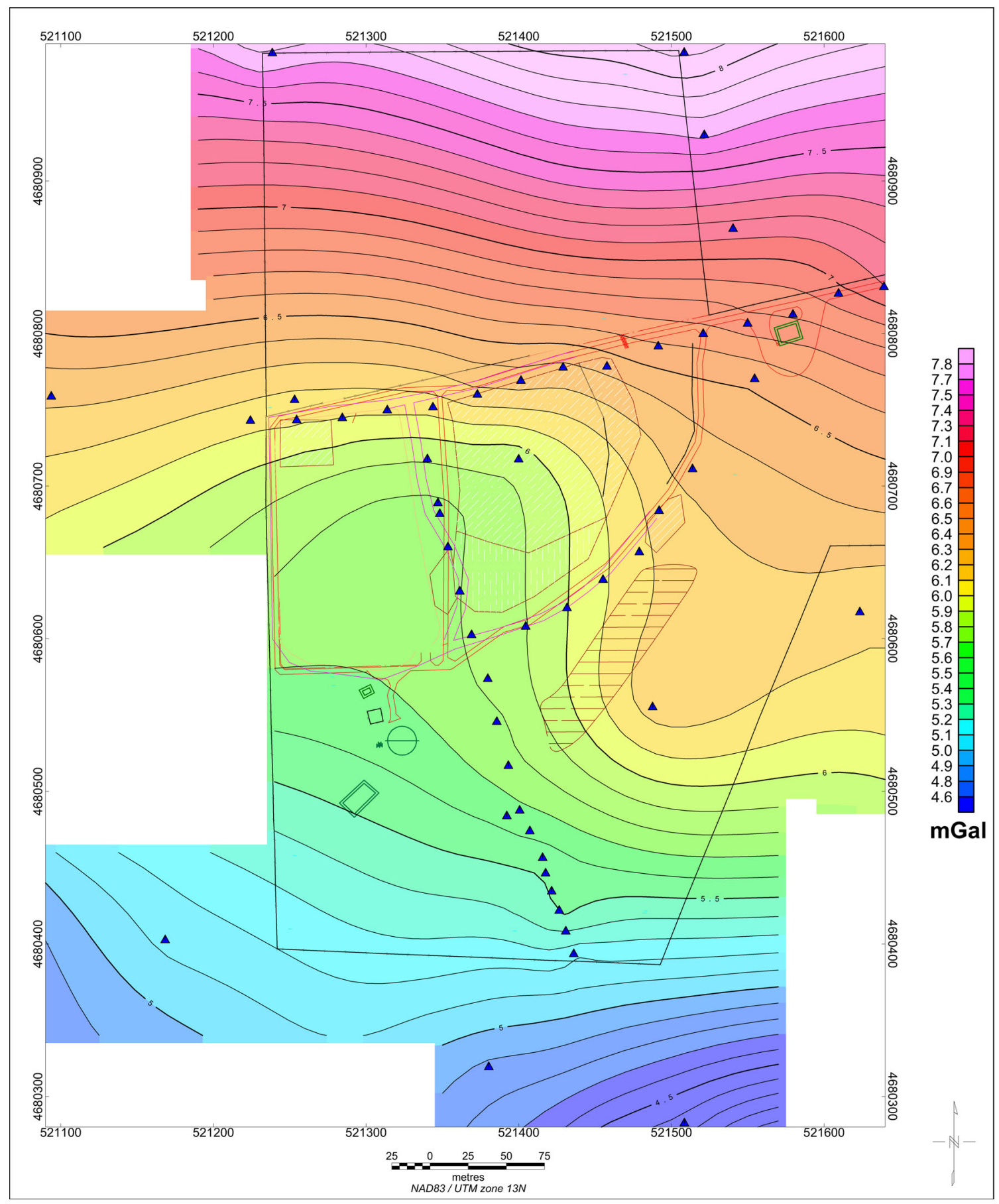

figure 5. Regional residual Bouguer gravity anomaly of the Guernsey landfill. 


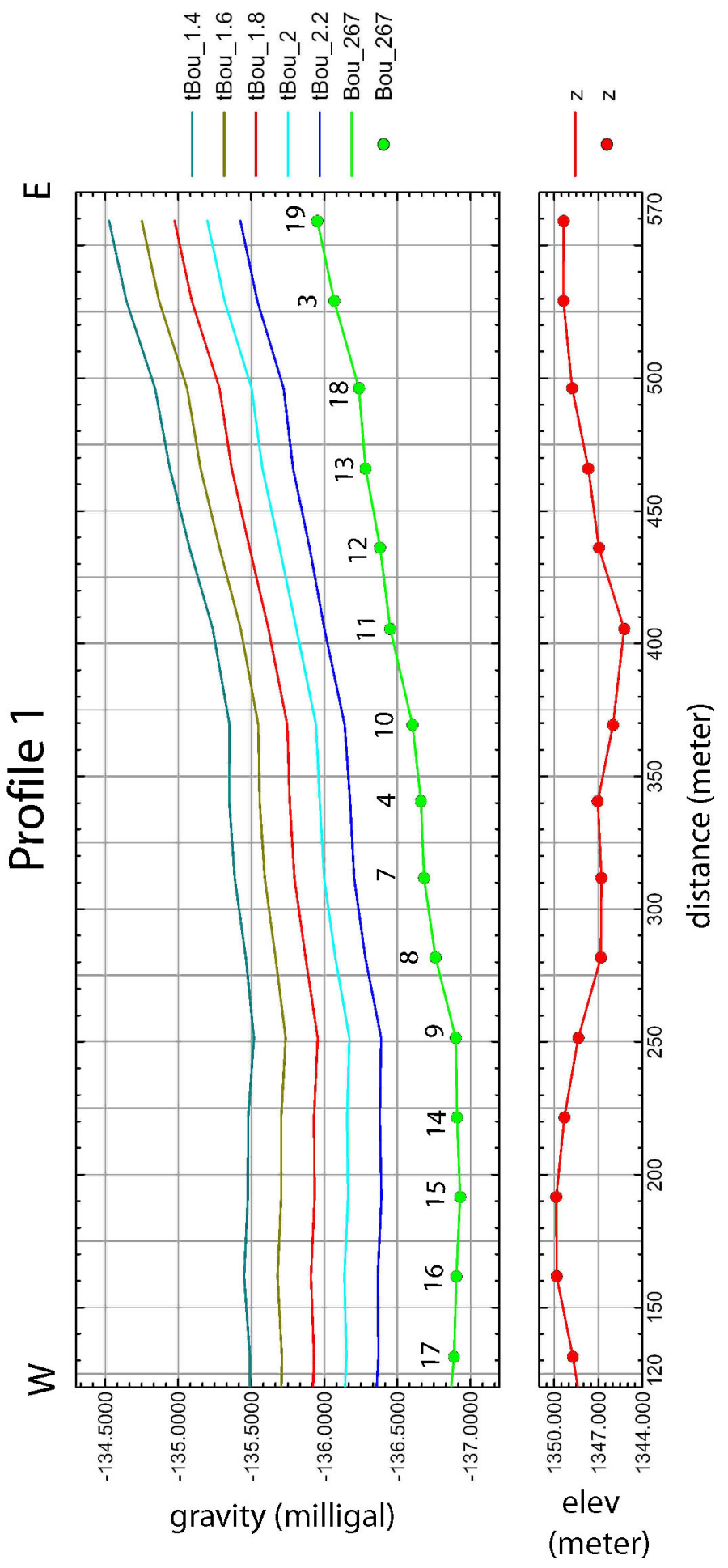

figure 6. Profile 1 showing Bouguer anomaly in red and the effect of terrace models at several densities. Gravity station locations are shown on the Bouguer and elevation curves. 

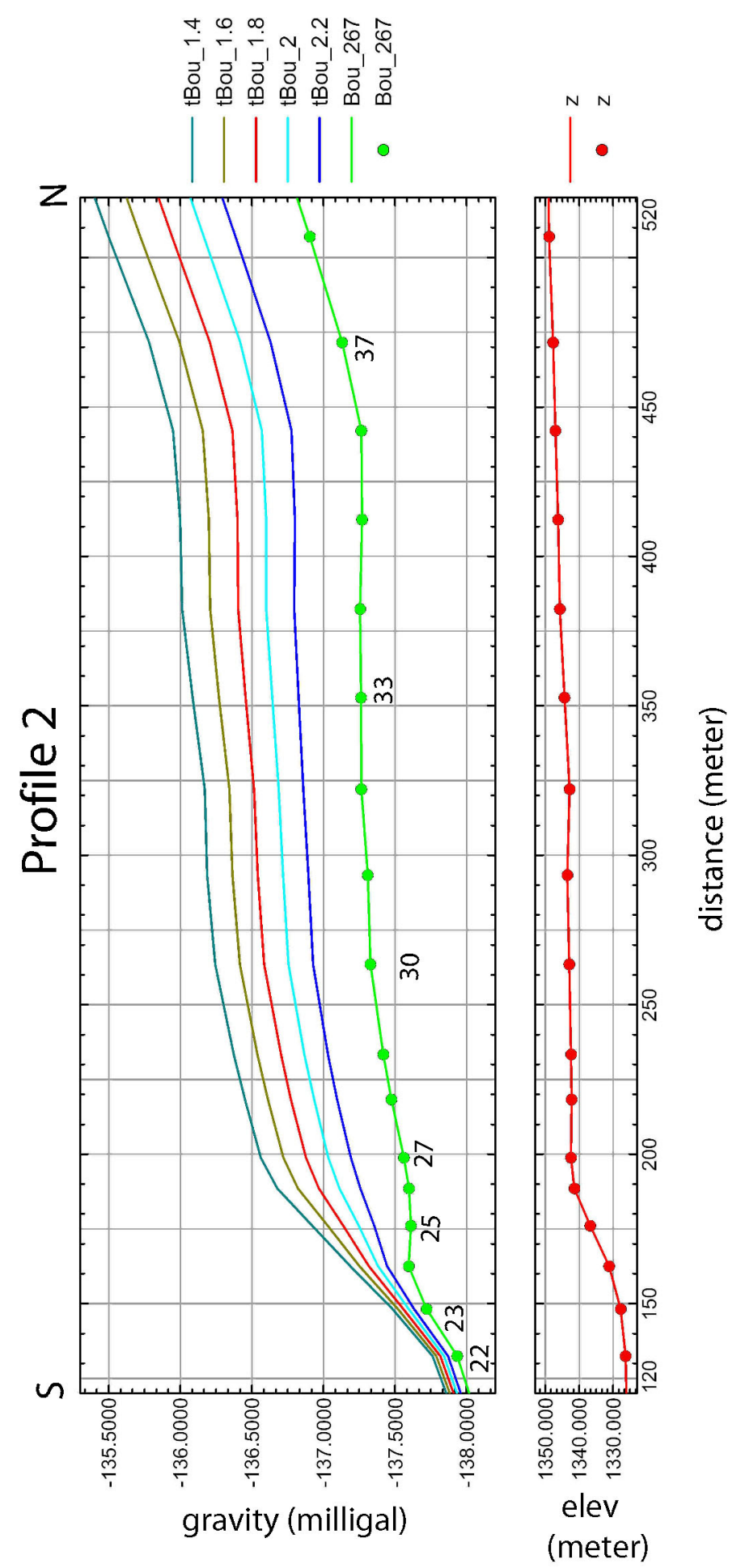

figure 7. South end of profile 2 showing Bouguer anomaly in red and effect of terrace models at several densities. 


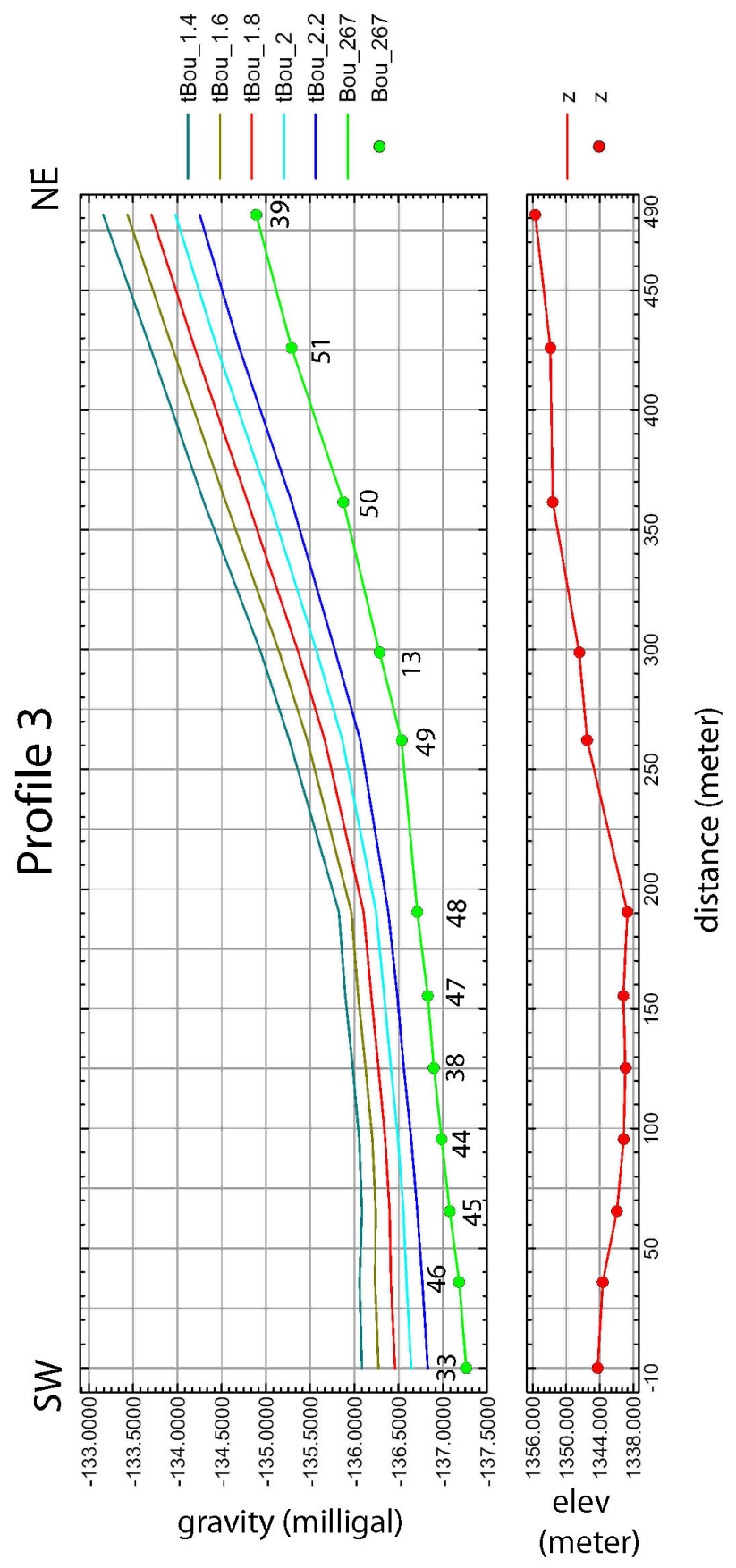

figure 8. Profile 3 showing Bouguer anomaly in red and the effect of terrace models at several densities. 


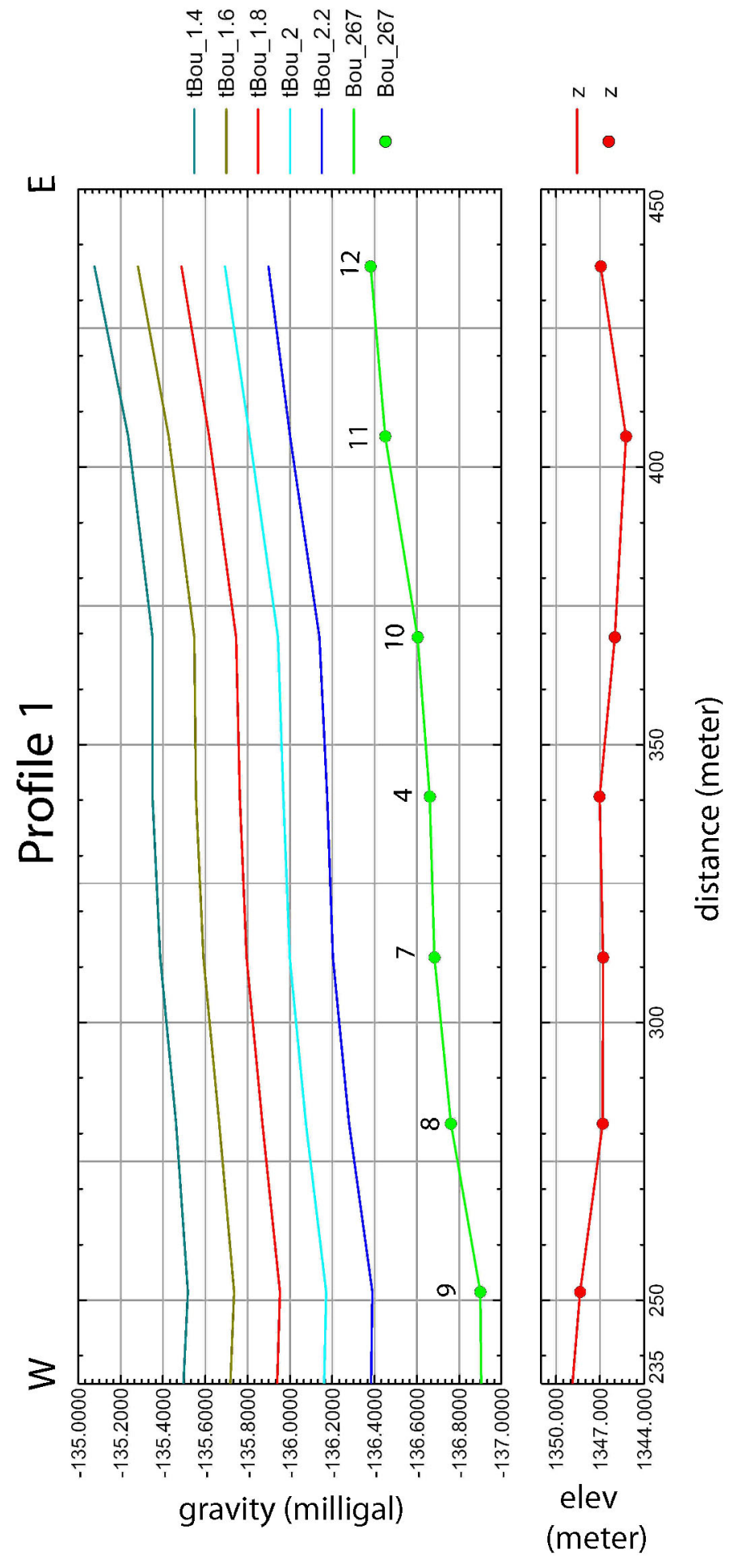

figure 9. Detail of profile 1 showing anomaly curvature reversals at stations g8, g4, and g11. 


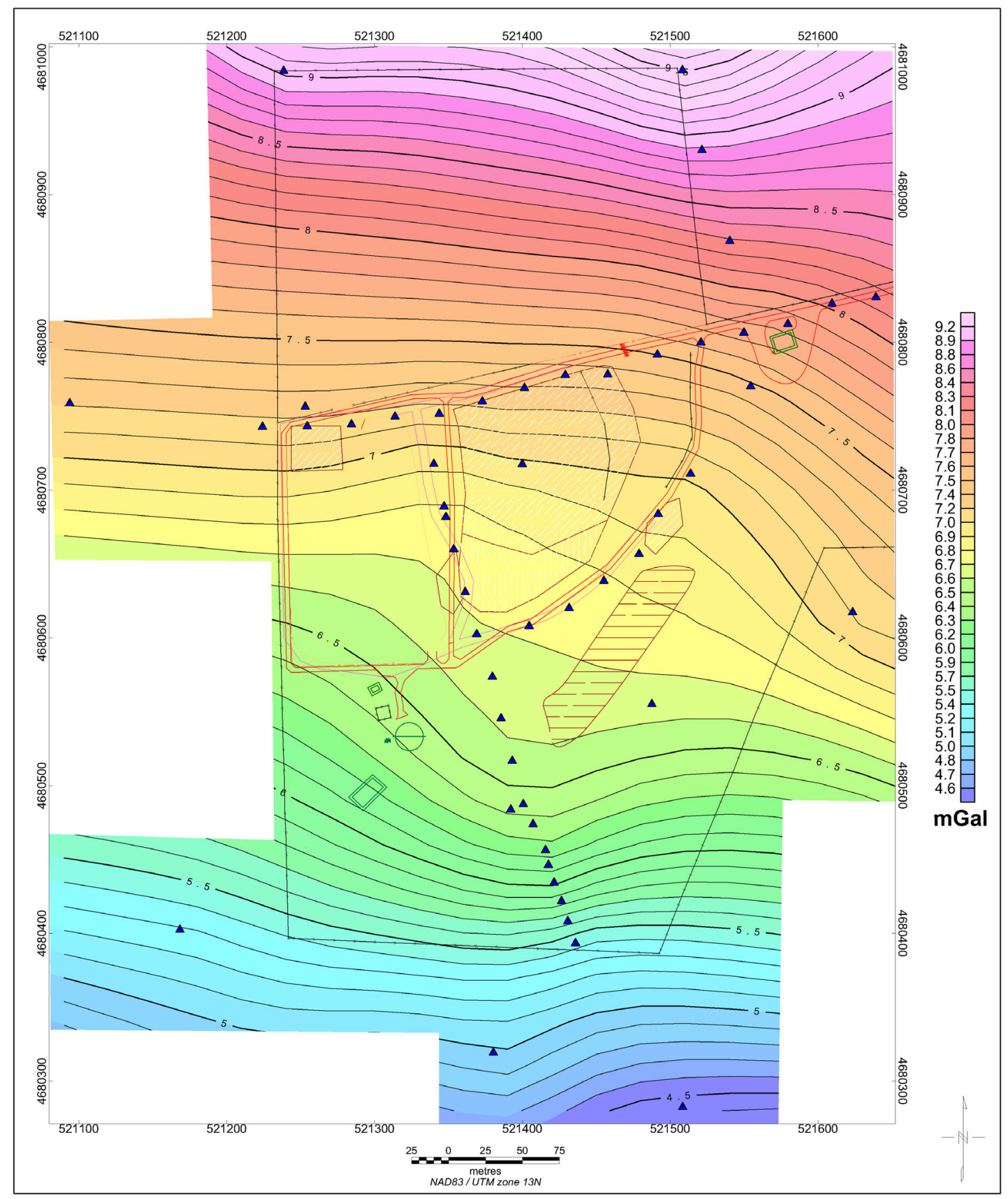

figure 10. Terrace residual gravity assuming a density of $1.80 \mathrm{gm} / \mathrm{cc}$. 


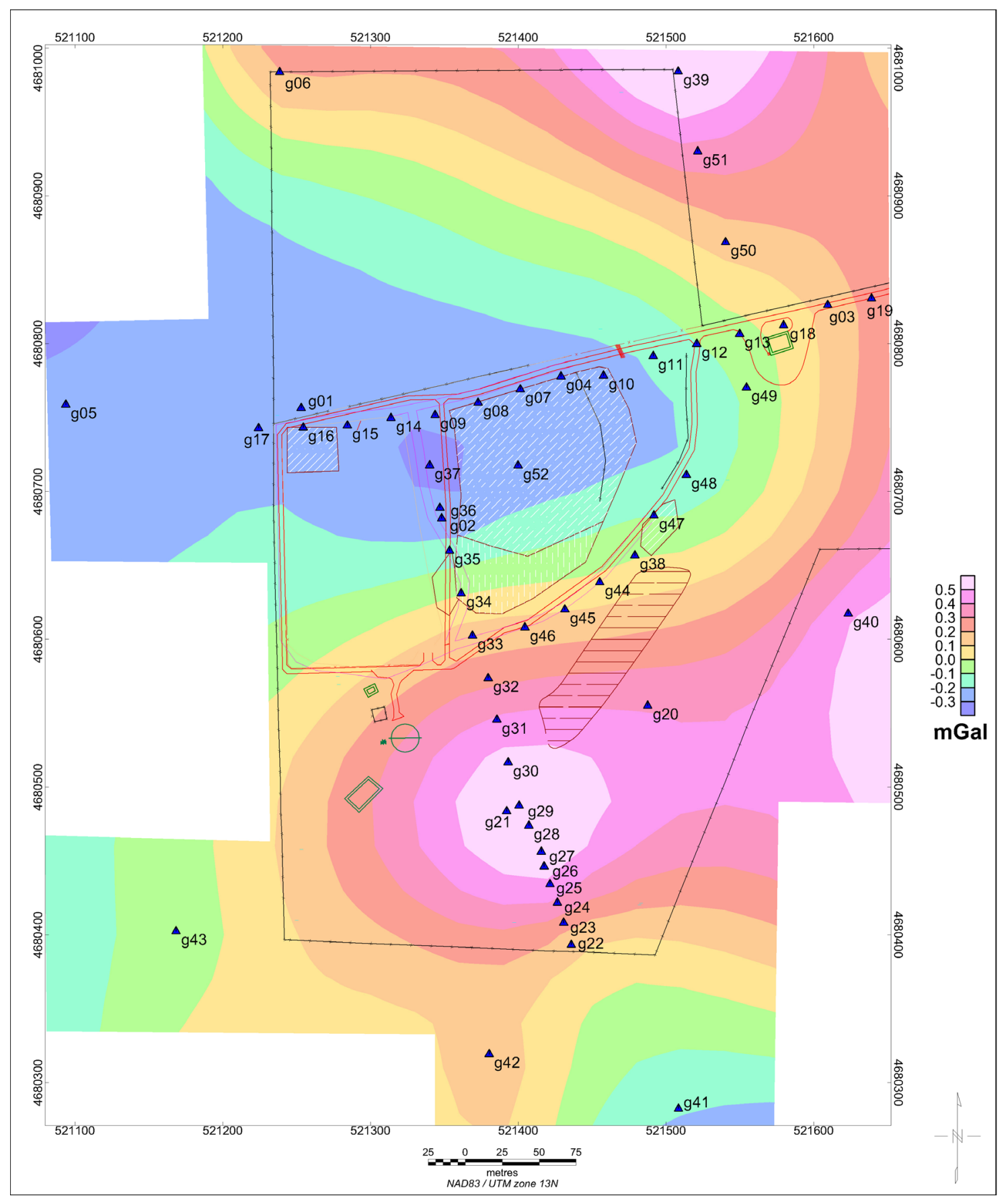

figure 11. De-trended terrace residual gravity. Landfill cells and roads in red, buildings in green. 


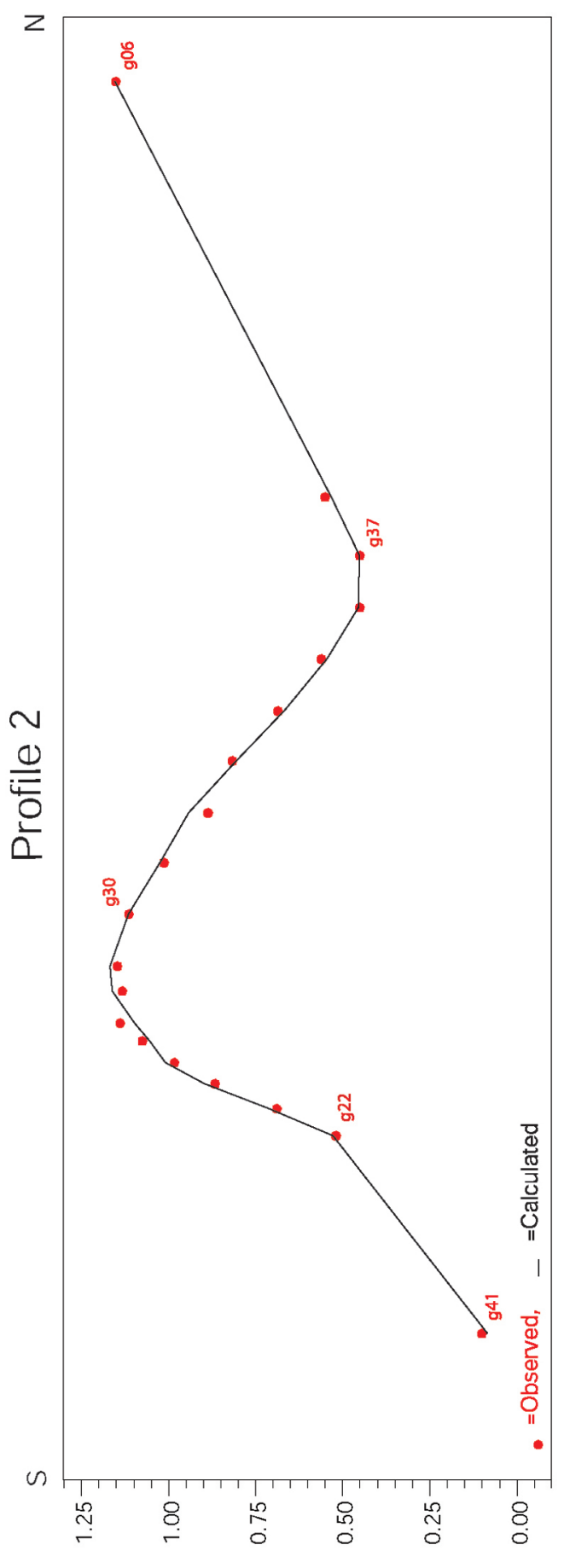

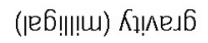

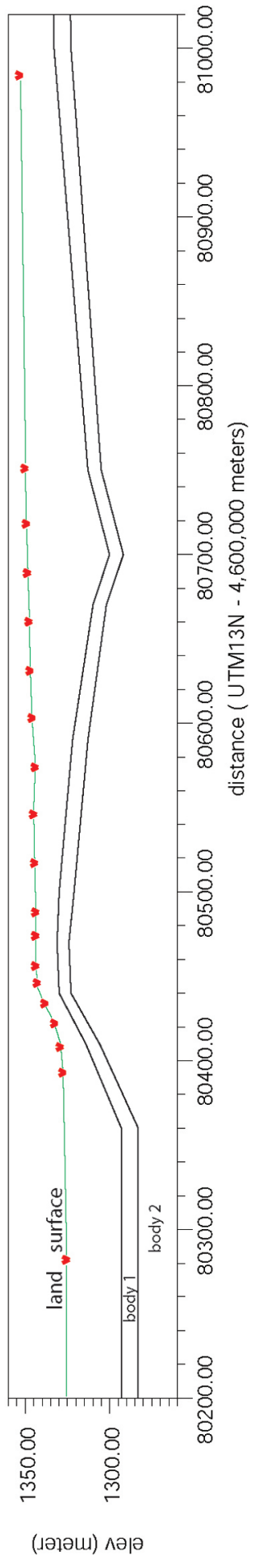

figure 12. 2.5D model from de-trended terrace residual gravity. Stations and gravity values shown in red, density reference is $1.80 \mathrm{gm} / \mathrm{cc}$, body 1 has a density contrast of $0.87 \mathrm{gm} / \mathrm{cc}$ and body 2 a contrast of $1.02 \mathrm{gm} / \mathrm{cc}$. 